\title{
Investeren in menselijk kapitaal:
}

Citation for published version (APA):

Montizaan, R., Nieste, M., \& Poulissen, D. (2019). Investeren in menselijk kapitaal: Een gecombineerd werknemers- en werkgeversperspectief. ROA. ROA Reports No. 001

https://doi.org/10.26481/umarep.2019001

Document status and date:

Published: 18/01/2019

DOI:

10.26481/umarep.2019001

Document Version:

Publisher's PDF, also known as Version of record

\section{Please check the document version of this publication:}

- A submitted manuscript is the version of the article upon submission and before peer-review. There can be important differences between the submitted version and the official published version of record.

People interested in the research are advised to contact the author for the final version of the publication, or visit the DOI to the publisher's website.

- The final author version and the galley proof are versions of the publication after peer review.

- The final published version features the final layout of the paper including the volume, issue and page numbers.

Link to publication

\footnotetext{
General rights rights.

- You may freely distribute the URL identifying the publication in the public portal. please follow below link for the End User Agreement:

www.umlib.nl/taverne-license

Take down policy

If you believe that this document breaches copyright please contact us at:

repository@maastrichtuniversity.nl

providing details and we will investigate your claim.
}

Copyright and moral rights for the publications made accessible in the public portal are retained by the authors and/or other copyright owners and it is a condition of accessing publications that users recognise and abide by the legal requirements associated with these

- Users may download and print one copy of any publication from the public portal for the purpose of private study or research.

- You may not further distribute the material or use it for any profit-making activity or commercial gain

If the publication is distributed under the terms of Article $25 \mathrm{fa}$ of the Dutch Copyright Act, indicated by the "Taverne" license above, 
Maastricht University

\section{Investeren in menselijk kapitaal:}

Een gecombineerd werknemers- en werkgeversperspectief

Raymond Montizaan

Merlin Nieste

Davey Poulissen

\section{ROA Rapport}

ROA-R-2019/1

Researchcentrum voor Onderwijs en Arbeidsmarkt | ROA Research Centre for Education and the Labour Market / ROA 


\section{Colofon}

(C) Researchcentrum voor Onderwijs en Arbeidsmarkt (ROA). Niets uit deze uitgave mag op enige manier worden verveelvoudigd zonder voorafgaande schriftelijke toestemming van de directeur van het ROA.

\section{Researchcentrum voor Onderwijs en Arbeidsmarkt}

Postbus 616

6200 MD Maastricht

$\mathrm{T}+31433883647$

$\mathrm{F}+31433884914$

secretary-roa-sbe@maastrichtuniversity.nl

www.roa.nl

School of Business and Economics

Maastricht University

\section{Vormgeving}

ROA secretariaat, Maastricht

ISBN: 978-90-5321-573-9

maart 2019 


\section{INHOUD}

\section{Samenvatting}

English summary

1 Introductie

2 Literatuur

2.1 Werkgevers en hun bereidheid om hun oudere werknemers te trainen

2.2 De bereidheid van oudere werknemers om te trainen

2.3 Omscholing versus Bijscholing

3 Surveydata en stated preferences experimenten

3.1 Voordelen en nadelen van vignettenonderzoek

3.2 Werkgeversexperiment

3.3 Werknemersexperiment

4 Resultaten

4.1 Werkgeversexperiment

4.2 Werknemersexperiment en vragenlijst 


\section{SAMENVATTING}

Investeringen in menselijk kapitaal door middel van trainingen en cursussen zijn een essentieel instrument om het concurrentievoordeel van bedrijven te behouden of te vergroten en zijn van groot belang om de employability van werknemers te vergroten. Ondanks de gebleken effectiviteit van training, tonen diverse studies aan dat de deelname aan trainingen niet gelijk verdeeld is over de werknemers. Vooral oudere werknemers participeren minder. De vraag is wat deze lagere participatie kan verklaren.

Dit rapport geeft inzicht in welke mate oudere werknemers in Nederland bereid zijn te investeren in hun menselijk kapitaal alsmede in hoeverre werkgevers bereid zijn om te investeren. Daartoe maken we gebruik van twee stated preferences experiments en surveys die zijn afgenomen in samenwerking met ABP. Deze stated preferences experiments bevatten vignetten die op causale wijze meten wat de mate van leeftijdsdiscriminatie bij trainingsallocaties is, alsmede de determinanten van de bereidheid van werknemers om te investeren.

Op basis van de resultaten van beide experimenten kunnen we vaststellen dat zowel werkgevers- als werknemersgedrag verantwoordelijk zijn voor de met leeftijd dalende participatie in opleidingen en cursussen. Desondanks zijn de resultaten voor werkgeversdiscriminatie iets sterker. Onder werknemers zien we weliswaar ook een met leeftijd afnemende motivatie om een cursus te volgen, maar deze afname verloopt vrij vlak tot 6o-jarige leeftijd. Onze resultaten leiden tot enkele concrete beleidsaanbevelingen:

- De relatie tussen trainingskansen en leeftijd verloopt veel vlakker voor werkgevers die relatief veel vaste contracten aanbieden en tevens veel ontwikkelgesprekken voeren met hun werknemers Dit duidt erop dat stabiele werksituaties, waarin wordt ingezet op een langere arbeidsrelatie en duurzame ontwikkeling, een positieve uitwerking hebben op het leven lang leren. Zowel werkgevers als werknemers worden dan gestimuleerd om na te denken over welke investeringen nodig zijn om de bestaande arbeidsrelatie op de lange termijn te laten slagen. Onze resultaten suggereren dus dat meer flexibiliteit op de arbeidsmarkt en het afbreken van de bescherming van de arbeidspositie van oudere werknemers weleens averechts kunnen werken voor het leven lang leren. Werkgevers krijgen zo minder incentives om te blijven investeren in het menselijk kapitaal van hun oudere werknemers. 
- De motivatie van werknemers om te investeren in hun menselijk kapitaal kan verder worden gestimuleerd als zij de vaardigheden die zij trainen ook kunnen gebruiken in hun privéleven. Daarnaast is autonomie in de onderwerpkeuze voor de opleiding of cursus van cruciaal belang voor de motivatie. Werknemers zijn veel meer gemotiveerd om te blijven investeren als zij medezeggenschap krijgen in de aard en wijze waarop geïnvesteerd gaat worden.

- Career plateauing is een cruciale factor die oudere werknemers demotiveert om te blijven investeren. Wil men leven lang leren stimuleren op latere momenten in de loopbaan, dan zal men ook loopbaanprofielen moeten aanpassen zodat werknemers nog steeds het gevoel hebben dat investeren in hun menselijk kapitaal beloond wordt.

- Oudere werknemers zijn minder bereid om hun vrije tijd op te offeren voor het volgen van opleidingen en cursussen. Hier speelt onder andere de grotere herstelbehoefte mee onder ouderen. Voor het stimuleren van een leven lang leren is het derhalve van belang dat voor oudere werknemers opleidingen en cursussen zo veel mogelijk gedurende werktijd worden aangeboden.

- Pensioenverwachtingen spelen een belangrijke rol bij de bereidheid om vrije tijd op te offeren voor het volgen van opleidingen en cursussen. Des te later een werknemer met pensioen denkt te gaan, des te groter is zijn of haar bereidheid. Maar er zijn heterogene effecten: werknemers die eerder met pensioen denken te gaan zijn meer gevoelig voor het trainingsbudget en de mate waarin de opleiding of cursus bruikbaar is in hun privéleven. 


\section{ENGLISH SUMMARY}

Investments in human capital through training and courses are an essential tool to maintain or increase the competitive advantage of companies and are of great importance to increase the employability of employees. Despite the proven effectiveness of training, various studies show that participation in training is not evenly distributed among employees. Especially older employees participate less. The question is what explains this lower participation.

This report provides insight into the extent to which older employees in the Netherlands are prepared to invest in their human capital and to what extent employers are prepared to invest in to older employees. To this end, we use two stated preference experiments and surveys that have been conducted in collaboration with ABP. These stated preferences experiments contain vignettes that measure causally the extent of age discrimination in training allocations, as well as the determinants of the willingness of employees to invest.

Based on the results of both experiments, we can conclude that both employer and employee behavior are responsible for the age-decreasing participation in education and training courses. Nevertheless, the results for employers' discrimination are somewhat stronger. Although we also see a negative relationship between age and the motivation to enroll in a course, the decrease in training motivation is fairly flat until the age of 60 . Our results lead to some concrete policy recommendations:

- The relationship between training opportunities and age is much flatter for employers who offer a relatively large number of permanent contracts and also have many development interviews with their employees. This indicates that stable work situations, which focus on a longer employment relationship and sustainable development, have a positive effect on lifelong learning. Both employers and employees are then encouraged to think about which investments are needed to make the existing employment relationship successful in the long term. Our results therefore suggest that more flexibility in the labor market and the abolition of the strong protection of the employment situation of older employees can sometimes be counterproductive for life-long learning. Employers receive fewer incentives to continue investing in the human capital of their older employees. 
- The motivation of employees to invest in their human capital can be further encouraged if they can also use the skills they train in their private lives. In addition, autonomy in the choice of subjects for the course is crucial for motivation. Employees are much more motivated to continue investing if they are given co-determination.

- Career plateauing is a crucial factor that demotivates older employees to continue investing. If one aims at encouraging lifelong learning over a longer lifespan, one will also have to adjust career profiles so that employees still have the feeling that investing in their human capital is rewarded.

- Older employees are less willing to sacrifice their free time for attending courses and courses due to a higher need for recovery. For the stimulation of lifelong learning, it is therefore important that older employees are offered training and courses as much as possible during working hours.

- Pension expectations play an important role in the willingness to sacrifice free time for attending training courses and courses. The sooner an employee thinks he or she is going to retire, the greater his or her willingness. But there are heterogeneous effects: employees who expect to retire earlier are more sensitive to the training budget and the extent to which the training or course is useful in their private life. 


\section{INTRODUCTIE}

Investeringen in menselijk kapitaal door middel van trainingen en cursussen zijn een essentieel instrument om het concurrentievoordeel van bedrijven te behouden of te vergroten en worden als een essentiële oplossing beschouwd voor de impact van de veroudering van het personeelsbestand op de productiviteit (Argote \& Ingram 2000; Lazazzara et al. 2013). Daarnaast zijn trainingen en cursussen van groot belang om de employability van werknemers te vergroten. Ze zijn een belangrijke bron van levenslang leren, die werknemers niet alleen helpen bij het verwerven van arbeidsgerelateerde kennis en vaardigheden, maar ook hun zelfvertrouwen en zelfperceptie verbeteren (OECD 2000; Becker 1975; Cromwell \& Kolb 2004; Aguinis \& Kraiger 2009; Lazazzara et al . 2013). Echter, ondanks de gebleken effectiviteit van training, tonen diverse studies aan dat de deelname aan trainingen niet gelijk verdeeld is over de werknemers. Vooral oudere werknemers participeren minder (Maurer 2001; Chiu et al. 2001; Hanson 2008; Fouarge et al. 2018; Künn-Nelen et al. 2018).

De factoren die van invloed zijn op deze lagere participatiegraad blijven onduidelijk. Werkgevers noemen vaak een gebrek aan betrokkenheid en een verminderde motivatie om te leren als redenen waarom oudere werknemers afzien van deelname aan training ( $N g$ \& Feldman 2012). Anderzijds hebben werkgevers wellicht ook minder incentives om te investeren in oudere werknemers. Allereerst omdat de terugverdientijd op de investering korter is. Ten tweede, omdat ouderen relatief veel verdienen, waardoor de opportuniteitskosten van trainingsinvesteringen relatief hoog liggen. En als laatste omdat werkgevers een tendens hebben om ouderen op de arbeidsmarkt te discrimineren. Trainingsparticipatiepercentages worden dus mogelijk beïnvloed door de voorkeuren en keuzes van zowel werknemers als werkgevers.

Dit rapport zal een beter inzicht proberen te geven op zowel de vraag in welke mate oudere werknemers in Nederland bereid zijn te investeren in hun menselijk kapitaal als op de vraag in hoeverre werkgevers bereid zijn om te investeren. Daartoe maken we gebruik van twee stated preferences experiments en surveys die zijn afgenomen in samenwerking met ABP. Deze stated preferences experiments bevatten vignetten die op causale wijze meten wat de mate van leeftijdsdiscriminatie bij trainingsallocaties is, alsmede de determinanten van de bereidheid van werknemers om te investeren. 
Onze contributie aan de bestaande literatuur en het beleidsdebat is dat onze analyses het mogelijk maken om afzonderlijk de bereidheid om te investeren in trainingen en cursussen te meten van werkgevers en werknemers. Aangezien de stated preferences experiments onderdeel zijn van uitgebreide surveys, zijn we verder in staat om te bepalen wat de kenmerken zijn van werkgevers en werknemers die de surveys hebben ingevuld. Dit stelt ons in staat om risicogroepen vast te stellen. 


\section{LITERATUUR}

\subsection{Werkgevers en hun bereidheid om hun oudere werknemers te trainen}

Werkgevers en werknemers kunnen beiden minder incentives hebben om op latere leeftijd te investeren in menselijk kapitaal. Voor werkgevers geldt dat bedrijven beginnen met minder te investeren in werknemers als deze 45 jaar oud zijn. Deze betrekkelijke jonge leeftijd wordt reeds gezien als het begin van de laatste fase van de loopbaan van werknemers (Maurer 2001; Van Vianen et al. 2009). Vanuit de literatuur worden verschillende verklaringen genoemd voor dit gedrag.

Eén van de belangrijkste verklaringen wordt gegeven door de human capital-theorie. Volgens deze theorie is investeren in menselijk kapitaal alleen aantrekkelijk als het rendement van trainingsinvesteringen opweegt tegen de kosten die daarbij worden gemaakt (Becker 1964). Bij het maken van deze kosten-baten analyse worden oudere werknemers vaak als een slechte investering gezien. Allereerst omdat oudere werknemers dichterbij hun pensionering staan en werkgevers derhalve in een minder lange periode hun trainingsinvesteringen moeten terugverdienen (Finkelstein \& Burke, 1998). Het kan derhalve voordeliger zijn om te investeringen in jongeren. Een belangrijk voorbehoud is daarbij dat jongeren ook werkzaam blijven bij dezelfde werkgever. Ten tweede omdat oudere werknemers doorgaans door met leeftijd oplopende loonprofielen meer verdienen dan jongere werknemers en dat derhalve de opportuniteitskosten van het volgen van trainingen en cursussen gedurende werktijd hoger liggen. Ten derde speelt mee dat ouderen minder snel leren dan jongeren doordat 'fluid intelligence' - ofwel het vermogen om nieuwe dingen aan te leveren - afneemt met leeftijd. Hierdoor zouden de trainingskosten voor ouderen weleens hoger kunnen liggen.

Daarnaast kan de waardevermindering van het menselijk kapitaal een verklaring zijn voor de kleinere opleidingskansen van oudere werknemers. De waardevermindering van het menselijk kapitaal kan worden veroorzaakt door twee soorten veroudering van vaardigheden: economische en technische veroudering. Veroudering van economische vaardigheden is een afname van de waarde van het menselijk kapitaal van werknemers omdat hun vaardigheden in hun baan achterhaald raken door technologische ontwikkelingen of verschuivingen in de vraag naar arbeid tussen sectoren of beroepen. 
Technische veroudering leidt tot aantasting van het menselijk kapitaal door atrofie of slijtage veroorzaakt door het verouderingsproces (de Grip \& van Loo, 2002). Zowel economische als technische veroudering kunnen zowel jonge als oudere werknemers treffen. Echter, bij het beheersen van bijvoorbeeld nieuwe computersoftware, doen oudere werknemers het vaak minder goed dan hun jongere collega's (Gist et al 1988). Bovendien zijn oudere werknemers vaak werkzaam in stervende industrieën waardoor het minder zin heeft om bestaande vaardigheden up-to-date te houden (Hutchens 1988; Lahey 2008).

Een andere verklaring voor de lagere bereidheid onder werkgevers om te investeren in trainingen en cursussen voor ouderen is dat zij leeftijdsdiscriminatie toepassen. Discriminatie kan worden onderverdeeld in twee soorten: statistische en 'taste based' discriminatie (Phelps 1972; Schwab 1986). Statistische discriminatie is gebaseerd op gemakkelijk waarneembare kenmerken zoals geslacht, ras, leeftijd of opleiding. Wanneer er een gebrek aan volledige informatie is, maken werkgevers onderscheid tussen individuen op basis van statistische regelmatigheden, omdat hun groepslidmaatschap relevante informatie, zoals productiviteit (Phelps 1972; Altonji \& Pierret 2001; Betrand et al. 2005) kan verschaffen. Taste based discriminatie, daarentegen is gebaseerd op persoonlijke preferenties van een persoon (Schwab 1986). Vaak worden deze persoonlijke preferenties gevoed door stereotypen (Hirsch et al. 2000; Chiu et al. 2001; Karpinska et al. 2011; Lazazzara et al. 2013; Karpinska et al. 2015).

\subsection{De bereidheid van oudere werknemers om te trainen}

De kosten-baten analyse die centraal staat in de human capital-theorie en de gevolgen van de veroudering van menselijk kapitaal kunnen eveneens ten grondslag liggen aan de lagere bereidheid van oudere werknemers om nog te trainen. Ook werknemers moeten afwegen of de baten van het volgen van een training nog afweegt tegen de kosten die deze met zich meebrengt. Daar zal career plateauing een belangrijke rol spelen. Career plateauing is de mate waarin werknemers ervaren dat zij geen progressie meer kunnen maken in hun organisatie en niet meer tot een hoger niveau kunnen uitgroeien. Logischerwijs zal een beperkte groei ook betekenen dat de baten van verdere investeringen in het menselijk kapitaal kleiner zullen zijn. Wat betreft de kostenzijde zullen werknemers naast de monetaire kosten ook kijken naar hun persoonlijke- en familiesituatie. Een voorbeeld hiervan is de herstelbehoefte. Deze meet de moeilijkheid die werknemers subjectief ervaren in het herstel na een dag werk, waarvan we weten dat deze substantieel stijgt met leeftijd (Mohren et al. 2010). Een hogere herstelbehoefte kan vervolgens betekenen dat oudere werknemers ook hogere kosten ervaren van het volgen van een training indien zij dit in hun eigen tijd moeten doen. 
Veel eerdere onderzoeken naar veroudering in organisaties hebben echter ook impliciet aangenomen dat veroudering zelf specifieke motivatieprocessen in de richting van leren activeert. Warr en Fay (2001) betogen in een theoretisch model dat werkmotivatie wordt beïnvloed door prikkels, gewoonten, vergelijkingen met (jongere) leeftijdsgenoten en sociale druk. Zo kan training meer tijdflexibiliteit vereisen en als een ongewilde onderbreking van routines worden beschouwd. En aangezien ouderen vooral baat hebben van taken die gebaseerd zijn op routine en crystalized intelligence, zouden zij hier een nadeel kunnen ervaren. Een vergelijking van de effectiviteit van trainingen met jongere leeftijdsgenoten kan er verder voor zorgen dat oudere werknemers minder gemotiveerd raken om te trainen als een dalende fluid intelligence ook leidt tot een verlaagd gevoel van zelfeffectiviteit (Maurer 2001; Maurer et al., 2008).

Eerdere onderzoeken over de relatie tussen trainingsbereidheid en de feitelijke trainingsparticipatie laten echter een inconsistent beeld zien. Bijvoorbeeld, in twee metaanalyses laten $\mathrm{Ng}$ en Feldman $(2008,2012)$ zien dat leeftijd negatief kan samenhangen met prestaties in trainingsprogramma's, motivatie voor loopbaanontwikkeling, motivatie om te leren, en de verwachte zelfeffectiviteit bij het leren. Ze laten echter ook zien dat leeftijd niet significant gerelateerd is aan deelname aan trainingen.

Maximiano (2011) analyseert zowel de bereidheid van werknemers als werkgevers om te trainen en laat zien dat verschillen in de trainingsparticipatie met leeftijd toch vooral worden gedreven door de bereidheid van werkgevers. Zwick (2015) geeft daarbij een interessant additioneel inzicht. Het verschil in effectiviteit van training over de levenscyclus komt vooral door hoe het trainingsbeleid van werkgevers wordt vormgegeven. Oudere werknemers hebben meer baat bij informele en direct relevante trainingscursussen die gerelateerd zijn aan hun crystalized intelligence, maar krijgen deze vorm van trainingen niet vaker aangeboden. Al met al moeten we derhalve concluderen dat er weinig bewijs is voor dat werknemers daadwerkelijk minder bereid zijn om te trainen. En als zij al minder bereid zijn, dan wordt dit deels veroorzaakt doordat het trainingsbeleid niet aansluit bij hun behoeften en voorkeuren.

\subsection{Omscholing versus Bijscholing}

Training kan twee vormen aannemen: omscholing en bijscholing. Bij omscholing zullen werknemers trainen om vervolgens in een andere functie bij dezelfde of een andere werkgever aan de slag te gaan. Bijscholing leidt tot een verbetering van de kennis en vaardigheden die werknemers gebruiken in hun huidige functie. Wat betreft de effectiviteit van beide trainingsvormen is van belang dat eerder onderzoek heeft aangegeven dat vooral bijscholing effectief is. Omscholing kan in principe ertoe bijdragen dat de inzetbaarheid voor andere banen en sectoren wordt vergroot. Echter, uit een eerder uitgevoerd werkgeversexperiment waarin werkgevers een keuze moesten maken tussen twee baanzoekenden, is gebleken dat investeringen in omscholing voor oudere werknemers nauwelijks effectief zijn (Montizaan \& Fouarge 2016). In het experiment werd gevarieerd met onder andere de leeftijd van baanzoekenden, de mate waarin 
vaardigheden up-to-date zijn en de relevante baanervaring. Daarbij kan de situatie waarin omscholing heeft plaatsgevonden worden omschreven als een werknemer die door omscholing betere vaardigheden heeft gekregen, maar nog geen werkervaring heeft opgebouwd in de specifieke baan waartoe hij of zij is omgeschoold. Uit het experiment blijkt dat de kans dat oudere omgeschoolde werknemers een baan aangeboden krijgen als de werkgever ook toegang heeft tot jongere werknemers nagenoeg $0 \%$ is. Omscholing leidt alleen tot substantiële verhogingen van de baankansen als deze voor 45-jarige leeftijd plaatsvindt en gecombineerd wordt met het opdoen van baanspecifieke ervaring. Echter, het is vooral van groot belang om bijscholing verder te stimuleren door de bereidheid van werknemers en werkgevers te verhogen. 


\section{SURVEYDATA EN STATED PREFERENCES EXPERIMENTEN}

\subsection{Voordelen en nadelen van vignettenonderzoek}

De reden dat we geen onderzoek doen naar revealed preferences is dat vignetten het specifieke voordeel hebben dat we werkelijke voorkeuren kunnen achterhalen van werknemers en werkgevers zonder dat hun onderlinge relatie hieraan beperkingen oplegt. Dit is een probleem bij revealed preferences data over trainingsparticipatie. Doorgaans staan deze data niet toe om te achterhalen of de werkgever, de werknemer of specifieke contextfactoren de oorzaak waren voor waarom er niet geïnvesteerd werd in het menselijk kapitaal van werknemers. Bovendien geven administratieve data meestal geen directe informatie over voorkeuren en zijn in deze datasets het aantal variabelen beperkt. Daardoor is het moeilijk om determinanten van trainingsparticipatie te achterhalen. Stated preferences experimenten daarentegen maken het mogelijk om de voorkeuren van werknemers en werkgevers van elkaar te onderscheiden en tevens om deze van hun context te isoleren.

Daarnaast zorgt de randomisering van de vignetkenmerken ervoor dat we causaal kunnen bepalen wat de impact is van de verschillende kenmerken op de kans om een training aangeboden te krijgen of op de bereidheid om een training te volgen in de eigen tijd. Dit is zeer relevant als we leeftijdsdiscriminatie willen meten en dit af willen zetten tegen de impact van werkervaring. Door deze zaken los te randomiseren zijn we bovendien in staat om de impact van leeftijd te isoleren van die van ervaring.

Stated preferences experimenten kunnen daarnaast de kloof tussen enquêteresultaten en revealed preferences verkleinen, aangezien ze een weerspiegeling zijn van echte beslissingen (Louvier et al., 2000). Het voordeel daarbij is dat enquêtes waarin stated preferences experimenten zijn opgenomen naast de gewone enquêtevragen dus ook revealed data opleveren in de setting van het experiment. Doordat daardoor veel meer informatie beschikbaar is over keuzegedrag, kenmerken van werknemers en kenmerken van werkgevers, kan veel dieper ingegaan worden op de determinanten van het keuzegedrag.

Onderzoeksexperimenten zoals vignetonderzoeken zijn daarnaast heel gebruikelijk in de sociale wetenschappen en winnen snel terrein in tal van andere disciplines, zoals 
economie. Hoewel oorspronkelijk ontworpen om normen te beoordelen, zijn vignetexperimenten erg handig om verschillende concepten zoals beslissingsgedrag en ouderdomgerelateerde onderwerpen te bestuderen.

Er zitten uiteraard ook potentiele nadelen aan vignettenexperimenten. De belangrijkste is dat vignetten uitsluitend hypothetische data genereren en mensen in de praktijk anders kunnen handelen dan dat zij zeggen te handelen in een theoretische situatie. Echter, er bestaat voldoende bewijs dat vignetexperimenten in staat zijn om gegevens te genereren die sterk lijken op gegevens uit veldexperimenten (Lawrence et al. 2006; Telser \& Zweifel 2007; Henkens et al 2009; Karpinska et al. 2011; Hainmueller et al. 2015).

\subsection{Werkgeversexperiment}

De gegevensverzameling onder werkgevers werd uitgevoerd door het Researchcentrum voor Onderwijs en Arbeidsmarkt (ROA) in 2012. Alle werkgevers in de publieke sector kregen een e-mail met daarin een link naar onze web-based survey, waarvan 1.057 werkgevers in de sectoren overheid en onderwijs (directe leidinggevenden, managing directors en HR-directeuren) het onderzoek hebben ingevuld. De survey bevatte het stated preferences experiment en diverse vragen over de kenmerken van de werkgever en de organisatie.

Het stated preferences experiment is gebaseerd op een vignettenonderzoek. Vignetten zijn concrete en gedetailleerde beschrijvingen van fictieve, maar realistische scenario's die zijn opgebouwd uit de praktijk, kennis, eerder onderzoek of verkennend onderzoek (Taylor, 2005). In dit vignet-experiment kregen werkgevers de hypothetische situatie voorgesteld dat hun organisatie een budget had gecreëerd om te investeren in de kennis en vaardigheden van haar medewerkers. Het vignet was als volgt opgebouwd:

De werkgever kreeg de mogelijkheid om te investeren in een bepaalde type training. In totaal waren er vier soorten trainingen die over de vignetten gerandomiseerd werden gevarieerd:

\section{Type training}

1. Leiding geven

2. Verbale en communicatieve vaardigheden

3. Ontwerp en ontwikkeling

4. Informatie zoeken \& verwerken

Vervolgens waren er twee beschrijvingen van hypothetische werknemers aan wie de werkgever de training kon aanbieden. De beschrijvingen van de werknemers verschilden op vijf kenmerken: 
1. Leeftijd

- 26-35 jaar

- 36-45 jaar

- 46-55 jaar

- 56-65 jaar

2. Geslacht

- Man

- Vrouw

3. Opleidingsniveau

- $\mathrm{MBO}$

- $\mathrm{HBO}$

- WO

4. Het aantal uren dat ze per week werkten

- 16 uur

- 32 uur

- 40 uur

5. Relevante werkervaring in jaren

- 5 jaar

- 10 jaar

- 15 jaar

Deze specifieke kenmerken van de werknemers zijn gekozen omdat zij, consistent met de human capital-theorie, voor werkgevers makkelijk meetbare indicatoren zijn voor het mogelijk rendement op hun investeringen in het menselijk kapitaal van hun werknemers.

Bijlage A toont een voorbeeld van een vignet. Gegeven alle variabelen en hun niveaus, werden 864 mogelijke combinaties van vignetten gemaakt (d.w.z. $4 \times 4 \times 2 \times 3 \times 3 \times 3$ ). Elke respondent moest zes keer kiezen tussen twee werknemers. De kenmerken werden willekeurig toegewezen, evenals, zoals eerder gezegd, het soort training. Ook de volgorde waarin de kenmerken werden gepresenteerd, verschilde steekproefsgewijs. 


\subsection{Werknemersexperiment}

De gegevensverzameling onder werknemers werd eveneens uitgevoerd door het Researchcentrum voor Onderwijs en Arbeidsmarkt (ROA). In totaal hebben 21.025 werknemers binnen de sectoren overheid en onderwijs de web-based survey ingevuld in 2017. De survey bevatte gedetailleerde vragen over pensioenverwachtingen, werkervaringen, de feitelijke trainingsparticipatie, trainingsbereidheid en het stated preferences experiment.

Trainingsparticipatie is als volgt gemeten: Heeft u in de afgelopen 12 maanden opleidingen of cursussen gevolg of volgt u die nog steeds?

De surveyvraag over trainingsbereidheid was als volgt gesteld: In hoeverre bent $u$ het eens met de onderstaande stellingen? I $\mathrm{k}$ ben bereid om opleidingen of cursussen te volgen wanneer dat nodig is voor een goede uitoefening van mijn functie. Mensen konden hierop antwoorden op een vijfpuntsschaal die loopt van 'zeer mee oneens' tot 'zeer mee eens'

Het stated preferences experiment bevat vervolgens vignetten die meten hoeveel uren werknemers bereid zijn om in hun eigen tijd een cursus te volgen. Daarmee geeft het antwoord op deze vignetten een directe indicatie van de motivatie van werknemers om te investeren in hun kennis en vaardigheden in hun eigen tijd. Het vignet was als volgt opgebouwd:

De werkgever stelt een trainingsbudget beschikbaar, maar vraagt of de werknemer bereid is om een deel van de training in de eigen tijd te volgen. De training zal 5 volledige werkdagen duren van 8 uur. In totaal duurt de cursus dus 40 uur. De cursusdagen worden verspreid over twee maanden. Vervolgens werd gevraagd hoeveel uur de werknemer bereid is om de training in de eigen tijd te volgen.

De volgende kenmerken van de cursus worden daarbij gerandomiseerd over de vignetten:

1. Het trainingsbudget

- 2000 euro

- 3500 euro

- 5000 euro

2. Bruikbaarheid van de opgedane kennis en vaardigheden

- Uitsluitend binnen uw organisatie

- In uw organisatie en in uw bedrijfstak

- In uw organisatie en in organisaties in en buiten uw bedrijfstak 


\section{Bruikbaarheid privé}

- Niet

- In beperkte mate

- Volledig

\section{De persoon die het onderwerp van de training kiest}

- Uw werkgever

- U en uw werkgever gezamenlijk

- Uzelf

Deze kenmerken geven een indicatie van de grootte van de investering en de bruikbaarheid van de training in de werksituatie en de persoonlijke situatie en zijn gebaseerd op de human capital-theorie. Specifiek voor ouderen zou men verwachten dat een grotere bruikbaarheid in de privésituatie hen over de streep zou kunnen trekken om te blijven investeren, zodat zij ook na hun pensioen profijt hebben van de training. De keuze van het onderwerp volgt vanuit diverse studies die hebben aangetoond dat ouderen meer autonomie nodig hebben in hun baan (e.g., Eichar et al. 1991).

Bijlage A2 toont een voorbeeld van een vignet. Elke respondent moest zes keer een vignet invullen. De kenmerken werden willekeurig toegewezen. Ook de volgorde waarin de kenmerken werden gepresenteerd verschilde steekproefsgewijs. 



\section{RESULTATEN}

\subsection{Werkgeversexperiment}

\subsubsection{Basis regressiemodel werkgeversexperiment}

Voor onze analyses van het werkgeversexperiment beginnen we met een linear probability model waarin we de kans dat iemand een training aangeboden krijgt regresseren op de leeftijd en de andere kenmerken van de werknemers in de vignetten:

$T O_{i t}=\alpha+\beta_{1} V A_{i t}+\delta X_{i t}+\varepsilon_{i t}$

Daarbij staat $T O_{i t}$ voor de dummy variabele die meet of een training wordt aangeboden door werkgever $i$ in vignette $t$. $V A_{i t}$ staat voor de leeftijd van werknemers $i$ in vignette $t$. $X_{i t}$ is een vector die alle controlevariablen bevat (bijvoorbeeld de andere vignettekenmerken zoals geslacht, relevante werkervaring, het aantal gewerkte uren) en $\varepsilon_{i t}$ is de errorterm. Omdat we meerdere observaties hebben per werkgever, passen we robust clustered standard errors toe in ons model. Zo corrigeren we voor heteroskedasticiteit op werkgeversniveau, wat er zou toe kunnen leiden dat de standaardfouten in ons model foutief te klein worden geschat.

\subsubsection{Basisresultaten werkgeversexperiment}

Tabel 1 geeft de resultaten weer van ons basis OLS-regressiemodel. Het blijkt dat werknemers die 56 jaar of ouder zijn een 17,6\% -punt lagere kans hebben om een training aangeboden te krijgen dan werknemers die 35 jaar of jonger zijn. Werkgevers in Nederland discrimineren dus inderdaad hun oudere werknemers, waarbij wel dient worden opgemerkt dat dit door pure discriminatie kan komen, maar ook door kosten-baten analyses of overwegingen met betrekking tot de snelheid tot leren. De term discriminatie moet hier dus niet letterlijk worden opgevat. 
TABEL 4.1 Basis resultaten: Werknemerskenmerken en de kans om een training aangeboden te krijgen

\begin{tabular}{|c|c|c|}
\hline Kans om een training aangeboden te krijgen & \multicolumn{2}{|c|}{ (1) OLS } \\
\hline 36-45 jaar (26-35 jaar = ref.) & -0.025 & $(0.020)$ \\
\hline 46-55 jaar & -0.028 & $(0.021)$ \\
\hline 56-65 jaar & $-0.176^{* * *}$ & $(0.022)$ \\
\hline 10 jaar ervaring ( 5 jaar = ref.) & $-0.043^{* *}$ & $(0.017)$ \\
\hline 15 jaar ervaring & $-0.070^{* * *}$ & $(0.019)$ \\
\hline 32 werkuren ( 16 werkuren = ref.) & $0.193^{* * *}$ & $(0.020)$ \\
\hline 40 werkuren & $0.221^{* * *}$ & $(0.020)$ \\
\hline Vrouw & $0.034^{* *}$ & $(0.017)$ \\
\hline MBO (HBO = ref.) & $-0.130^{* * *}$ & $(0.023)$ \\
\hline wo & $-0.146^{* * *}$ & $(0.019)$ \\
\hline Observations & 6,344 & \\
\hline R-squared & 0.081 & \\
\hline
\end{tabular}

Werkervaring vermindert eveneens de kans op opleidingsmogelijkheden. Na 10 jaar ervaring vermindert de kans op trainingsmogelijkheden met 4,3\% -punten ten opzichte van mensen met 5 jaar ervaring en werknemers met 15 jaar ervaring hebben een $7 \%$-punten lagere kans. Dit duidt erop dat opportuniteitskosten een belangrijke rol kunnen spelen bij de bereidheid van werkgevers om een training aan te bieden aan hun oudere werknemers.

Mensen die meer uren werken hebben een hogere kans: werknemers die 32 uur per week werken hebben een 19,3\%-punten hogere kans op training dan werknemers die maar 16 uur per week werken. De kans op training is 22,1\%-punt hoger voor werknemers die 40 uur werken. Dit duidt eveneens op een investeringsmotief. De tijd waarin de trainingsinvestering moet worden terugverdiend is immers groter voor mensen die meer uren werken.

De negatieve coëfficiënten voor het WO-opleidingsniveau en het MBO-opleidingsniveau kunnen verklaard worden door de opzet van het vignet. De training wordt immers op HBO-niveau aangeboden.

Vrouwen hebben eveneens een grotere kans op een trainingsaanbod: een 3.4\%-punten grotere kans. Dit resultaat is consistent met eerdere studies (e.g., Fritsche 2012; Tan et al. 2015; Cloutier et al., 2008). Een studie van Arulampalam e.a.. (2004) laat zien dat in Nederland de trainingsparticipatie vooral afneemt voor mannen met leeftijd. De reden 
hiervoor is dat zij vaker vaste contracten hebben en zich dus minder genoodzaakt voelen om te trainen. Omdat vrouwen meer in beroepen zitten met flexibele arbeidsvoorwaarden, voelen zij vaker de noodzaak om te blijven trainen. Mogelijkerwijs speelt deze overweging ook mee bij de keuzes van werkgevers.

We hebben in vervolganalyses eveneens gekeken naar de interactie-effecten tussen de verschillende werknemerseffecten. Interessant is dat er geen significante interactieeffecten zijn tussen de leeftijd van de werknemers en hun andere kenmerken. Dus ongeacht geslacht, het aantal gewerkte uren, werkervaring en opleidingsniveau heeft leeftijd altijd een negatieve impact op de kans om een training aangeboden te krijgen. Daarnaast hebben we gekeken naar interacties met het soort training. Ook hier geldt dat we geen significante interactie-effecten hebben gevonden. Met andere woorden, werkgevers zijn dus niet geneigd om specifieke trainingen vaker of minder vaak aan te bieden aan oudere werknemers. Dit is zorgwekkend aangezien Zwick (2015) al eerder aantoonde dat het trainingsbeleid van werkgevers niet optimaal is vormgegeven doordat het trainingsbeleid niet aansluit bij de behoeften en voorkeuren van oudere werknemers.

\subsubsection{Kans op een trainingsaanbod en type werkgever}

We hebben in onze dataset gedetailleerde informatie over werkgevers verzameld. Dit stelt ons in staat om te analyseren welke werkgevers meer of minder op leeftijd discrimineren in hun trainingsbeleid. Uit regressieanalyses waarin we de attributen van ons vignet interacteren met de kenmerken van de werkgevers komt een interessant patroon naar voren. Veelal zijn er geen significante interactie-effecten, maar opvallend is dat de relatie tussen trainingskansen en leeftijd veel vlakker verloopt voor werkgevers die relatief veel vaste contracten aanbieden (Figuur 4.1) en tevens veel ontwikkelgesprekken voeren met hun werknemers (Figuur 4.2). Dit duidt erop dat een stabiele werksituatie, waarin wordt ingezet op een langere arbeidsrelatie en duurzame ontwikkeling, een positieve uitwerking kan hebben op een leven lang leren. Zowel werkgevers als werknemers worden dan gestimuleerd om na te denken over welke investeringen nodig zijn om de bestaande arbeidsrelatie op de lange termijn te laten slagen.

Een conclusie die uit deze bevindingen kan worden getrokken is dat een verdere flexibilisering van de arbeidsmarkt dus weleens een negatieve invloed kan hebben op de kansen van oudere werknemers om zich te kunnen blijven ontwikkelen. In een omgeving waarin flexibele contracten worden aangeboden of minder ontwikkelingskansen zijn staan zij immers als laatste in de rij voor het trainingsaanbod. Daarbij dient echter te worden opgemerkt dat bedrijven met relatief veel vaste contracten of ontwikkelgesprekken ook andere specifieke kenmerken kunnen hebben die deze relatie beïnvloedt. Echter, deze resultaten bieden in ieder geval stof tot nadenken voor beleidsmakers. 
FIGUUR 4.1 Marginale effecten van basismodel, geïnteracteerd met percentage vaste contracten

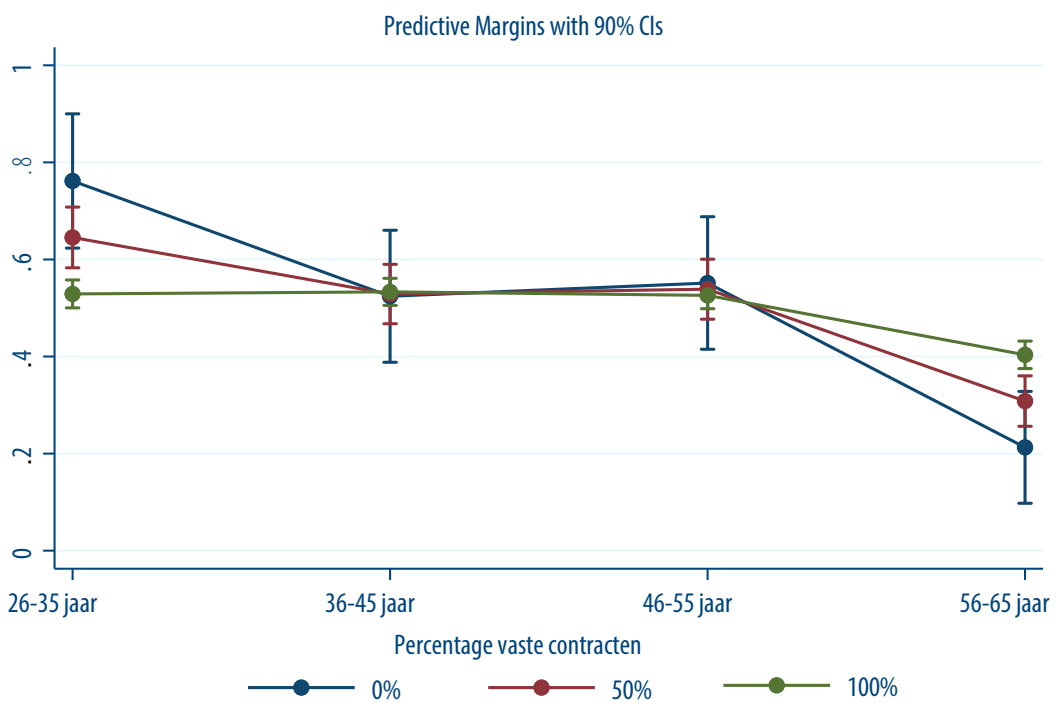

FIGUUR 4.2 Marginale effecten van basismodel, geïnteracteerd met frequentie ontwikkelgesprekken

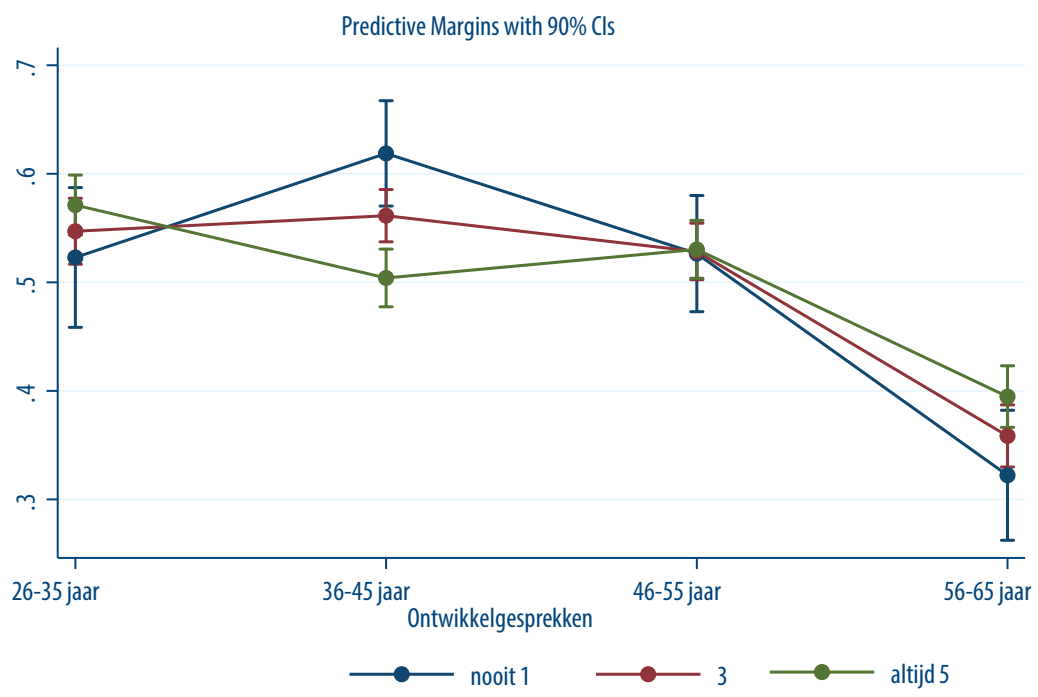




\subsection{Werknemersexperiment en vragenlijst}

\subsubsection{Basis regressiemodellen: bereidheid om te trainen en werknemerssexperiment}

Voor onze analyses van het werknemersexperiment hanteren we eenzelfde identificatiestrategie als bij onze analyses op het werkgeversexperiment. We beginnen met een OLS-regressiemodel waarin we het aantal uren dat mensen willen trainen in hun vrije tijd regresseren op de leeftijd en de andere kenmerken van de werknemers in de vignetten:

$$
U R_{i t}=\alpha+\pi_{1} X_{i t}+\pi Z_{i t}+\varepsilon_{i t}
$$

Daarbij staat $U R_{i t} s$ voor het aantal uren dat werknemer $i$ in vignette $t$ in zijn of haar eigen tijd wil trainen. $X_{i t}$ staat voor de vignetkenmerken in vignette $t . Z_{i t}$ is een vector die alle controlevariablen bevat en $\varepsilon_{i t}$ is de errorterm. Omdat we ook hier meerdere observaties hebben per werknemer, passen we weer robust clustered standard errors toe in ons model.

Daarnaast schatten we een OLS-regressiemodel op de trainingsparticipatie en de bereidheid om opleidingen of cursussen te volgen wanneer dat nodig is voor een goede uitoefening van de functie. In tegentelling tot het vignettenexperiment, wordt deze bereidheid maar één keer gemeten.

\subsubsection{Basisresultaten}

De algemene bereidheid om opleidingen of cursussen te volgen onder werknemers is groot. $78,8 \%$ van alle werknemers is het eens of zeer mee eens met de stelling dat zij bereidheid zijn om opleidingen of cursussen te volgen als dit nodig zou zijn voor hun functie. Wel valt op te maken uit Tabel 4.2 dat werknemers in het Voortgezet onderwijs iets minder vaak bereid zijn om opleidingen en cursussen te volgen.

Tabel 4.2 laat echter ook zien dat de bereidheid om opleidingen of cursussen te volgen significant afneemt met leeftijd. Vooral na 60 jaar neemt de bereidheid sterk af. Desalniettemin kan op basis van deze analyse niet ontkend worden dat oudere werknemers iets minder vaak bereid zijn om opleidingen en cursussen te volgen. 
TABEL 4.2 Basis resultaten: Werknemerskenmerken en de bereidheid om opleidingen of cursussen te volgen

\begin{tabular}{|c|c|c|}
\hline \multirow{2}{*}{$\begin{array}{l}\text { VARIABLES } \\
\text { Leeftijd 31-40 jaar ( }<31 \text { jaar = ref.) }\end{array}$} & \multicolumn{2}{|c|}{$\begin{array}{l}\text { (1) } \\
\text { Bereidheid om te trainen }\end{array}$} \\
\hline & $-0.090^{*}$ & $(0.053)$ \\
\hline Leeftijd 41-50 jaar & $-0.169^{* * *}$ & $(0.050)$ \\
\hline Leeftijd 51-60 jaar & $-0.390^{* * *}$ & $(0.048)$ \\
\hline Leeftijd 61-70 jaar & $-0.864^{* * *}$ & $(0.050)$ \\
\hline Basisonderwijs (VMBO $==$ ref) & $-0.397^{* * *}$ & (0.145) \\
\hline HAVO / VWO & $0.251^{* * *}$ & $(0.034)$ \\
\hline MBO & $0.202^{* * *}$ & $(0.030)$ \\
\hline HBO & $0.378^{* * *}$ & $(0.028)$ \\
\hline wo & $0.540^{* * *}$ & $(0.031)$ \\
\hline Postacademisch & $0.508^{* * *}$ & $(0.037)$ \\
\hline Nettoloon (In) & $0.147^{* * *}$ & $(0.022)$ \\
\hline \multicolumn{3}{|l|}{ Sectoren (Rijk is ref.) } \\
\hline Voorgezet onderwijs & $-0.110^{* * *}$ & $(0.027)$ \\
\hline Constant & $2.955^{* * *}$ & $(0.176)$ \\
\hline Observations & 18,310 & \\
\hline R-squared & 0.135 & \\
\hline
\end{tabular}


FIGUUR 4.3 Basis resultaten: Werknemerskenmerken en trainingsparticipatie

\begin{tabular}{|c|c|c|}
\hline \multirow{2}{*}{$\begin{array}{l}\text { VARIABLES } \\
\text { Leeftijd } 31-40 \text { jaar }(<31 \text { jaar = ref.) }\end{array}$} & \multicolumn{2}{|c|}{$\begin{array}{c}\text { (1) } \\
\text { Trainingsparticipatie }\end{array}$} \\
\hline & -0.045 & $(0.038)$ \\
\hline Leeftijd 41-50 jaar & $-0.080^{* *}$ & $(0.036)$ \\
\hline Leeftijd 51-60 jaar & $-0.162^{* * *}$ & $(0.035)$ \\
\hline Leeftijd 61-70 jaar & $-0.271^{* * *}$ & $(0.035)$ \\
\hline Basisonderwijs (VMBO = ref.) & -0.035 & $(0.060)$ \\
\hline HAVO / VWO & $0.042^{* *}$ & $(0.017)$ \\
\hline MBO & $0.057^{* * *}$ & $(0.014)$ \\
\hline HBO & $0.121^{* * *}$ & $(0.013)$ \\
\hline wo & $0.135^{* * *}$ & $(0.016)$ \\
\hline Postacademisch & $0.159^{* * *}$ & $(0.020)$ \\
\hline Nettoloon (In) & $0.070^{* * *}$ & $(0.012)$ \\
\hline \multicolumn{3}{|l|}{ Sectoren (Rijk is ref.) } \\
\hline Provincies en Waterschappen & $0.059^{* * *}$ & $(0.023)$ \\
\hline Gemeenten & $0.023^{*}$ & $(0.012)$ \\
\hline Politie & $-0.079^{* * *}$ & $(0.016)$ \\
\hline Primair onderwijs & $0.170^{* * *}$ & $(0.015)$ \\
\hline Voortgezet onderwijs & $0.081^{* * *}$ & $(0.014)$ \\
\hline Hoger beroepsonderwijs & $0.037^{*}$ & $(0.020)$ \\
\hline Wetenschappelijk onderwijs & $-0.092^{* * *}$ & $(0.019)$ \\
\hline Beroeps en volwasseneneducatie & $0.087^{* * *}$ & $(0.018)$ \\
\hline Acadmische medische centra & $-0.043^{*}$ & $(0.022)$ \\
\hline Constant & -0.001 & $(0.095)$ \\
\hline Observations & \multicolumn{2}{|l|}{18,549} \\
\hline R-squared & \multicolumn{2}{|l|}{0.057} \\
\hline
\end{tabular}

Figuur 4.3 laat vervolgens de causale vignettenresultaten zien waaruit blijkt hoeveel uren werknemers bereid zijn om in hun eigen tijd een cursus te volgen. Gemiddeld genomen zijn werknemers bereid om bijna 12 uur van hun vrije tijd in te zetten. De belangrijkste factoren die deze bereidheid verklaren zijn de bruikbaarheid van de cursus in het privéleven en de persoon die de cursus heeft uitgekozen. Als mensen zelf de cursus kunnen uitkiezen draagt dit bij tot een 4 uur hogere inzet van vrije tijd dan dat als hun werkgever de training kiest. Eenzelfde effect is zichtbaar voor de bruikbaarheid van de vaardigheden die zijn getraind. Als deze bruikbaar zijn in het privéleven, dan zijn werknemers bereid om ongeveer 4 uur meer in te zetten dan als deze totaal niet bruikbaar zijn. Het trainingsbudget en de bruikbaarheid in het werk hebben eveneens een significant effect op de inzet van uren, maar de effecten zijn veel kleiner. En stijging van het trainingsbudget met 3.000 euro leidt maar tot een stijging in de ingezette uren met ongeveer 1,3 uur. Ofwel, het geven van volledige autonomie in de trainingskeuze is 
bijna 3 keer zo effectief in het verhogen van de ingezette uren dan het verhogen van het trainingsbudget met 3.000 euro. De mogelijkheid om vaardigheden die zijn opgedaan in de cursus toe te passen in de privésituatie is daarnaast drie keer zo effectief dan het verhogen van de bruikbaarheid van de cursus naar organisaties binnen en buiten de eigen bedrijfstak.

FIGUUR 4.4 Basis resultaten: Bereidheid om opleidingen en cursussen te volgen in eigen tijd in vignetten experiment

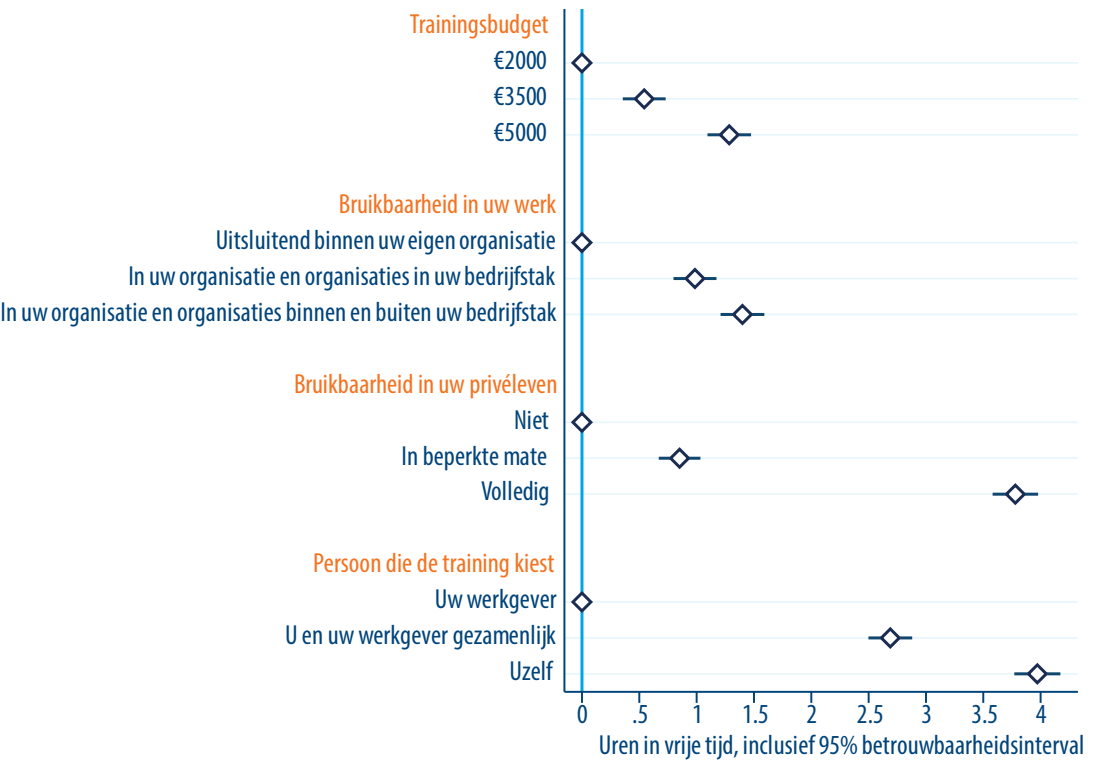


TABEL 4.3 Werknemerskenmerken en bereidheid om opleidingen en cursussen te volgen in eigen tijd

\begin{tabular}{|c|c|c|}
\hline \multirow{2}{*}{$\begin{array}{l}\text { VARIABLES } \\
\text { Bereidheid om te trainen in eigen tijd (in uren) }\end{array}$} & \multicolumn{2}{|c|}{$\begin{array}{l}\text { (1) } \\
\text { Bereidheid om te trainen in eigen tijd (in uren) }\end{array}$} \\
\hline & -0.045 & $(0.038)$ \\
\hline Leeftijd 41-50 jaar & $-0.080^{* *}$ & $(0.036)$ \\
\hline Leeftijd 51-60 jaar & $-0.162^{* * *}$ & $(0.035)$ \\
\hline Leeftijd 61-70 jaar & $-0.271^{* * *}$ & $(0.035)$ \\
\hline Basisonderwijs (VMBO = ref.) & -0.035 & $(0.060)$ \\
\hline HAVO / VWO & $0.042^{* *}$ & $(0.017)$ \\
\hline MBO & $0.057^{* * *}$ & $(0.014)$ \\
\hline HBO & $0.121^{* * *}$ & $(0.013)$ \\
\hline wo & $0.135^{* * *}$ & $(0.016)$ \\
\hline Postacademisch & $0.159^{* * *}$ & $(0.020)$ \\
\hline Nettoloon (In) & $0.070^{* * *}$ & $(0.012)$ \\
\hline \multicolumn{3}{|l|}{ Sectoren (Rijk is ref.) } \\
\hline Provincies en Waterschappen & $0.059^{* * *}$ & $(0.023)$ \\
\hline Gemeenten & $0.023^{*}$ & $(0.012)$ \\
\hline Politie & $-0.079^{* * *}$ & $(0.016)$ \\
\hline Primair onderwijs & $0.170^{* * *}$ & $(0.015)$ \\
\hline Voortgezet onderwijs & $0.081^{* * *}$ & $(0.014)$ \\
\hline Hoger beroepsonderwijs & $0.037^{*}$ & $(0.020)$ \\
\hline Wetenschappelijk onderwijs & $-0.092^{* * *}$ & $(0.019)$ \\
\hline Beroeps en volwasseneneducatie & $0.087^{* * *}$ & $(0.018)$ \\
\hline Acadmische medische centra & $-0.043^{*}$ & $(0.022)$ \\
\hline Constant & -0.001 & $(0.095)$ \\
\hline Observations & \multicolumn{2}{|l|}{18,549} \\
\hline R-squared & \multicolumn{2}{|l|}{0.057} \\
\hline \multicolumn{3}{|c|}{ OLS-schattingen met robust standard errors die gecorrigeerd zijn voor clustering. ${ }^{* *} p<0.01,{ }^{* *}$} \\
\hline
\end{tabular}

Tabel 4.4. laat vervolgens zien hoe werknemerskenmerken correleren met het aantal uur dat men wil trainen in de eigen tijd. Uit de tabel blijkt eenzelfde beeld als bij de algemene bereidheid om opleidingen of cursussen te volgen. Het aantal uren dat werknemers van hun vrije tijd willen inzetten om een cursus te volgen neemt significant af met leeftijd. Vooral na 60-jarige leeftijd daalt het aantal ingezette uren snel (bijna 7,2 uur minder). Het leeftijdseffect tot 60-jarige leeftijd blijft echter beperkt tot 4,6 uur, wat ongeveer gelijk is aan het opleidingseffect. Een persoon met een WO-opleiding is bereid om eveneens 4 uur meer van hun vrije tijd in te zetten dan iemand met een VMBO-diploma. En verder is de associatie van een daling in het nettoloon met maar $4 \%$ equivalent aan die van een stijging van onderste tot aan de bovenste leeftijdscategorie. Dus ook hier geldt 
dat oudere werknemers iets minder gemotiveerd zijn om opleidingen of cursussen te volgen, maar dat de afname toch beperkt is als men deze vergelijkt met de impact van andere determinanten van de trainingsbereidheid.

Verder is er sprake van behoorlijke sectorale verschillen in de bereidheid om vrije uren in te zetten voor het volgen van een cursus. Bij de meeste onderwijssectoren is deze bereidheid relatief hoog.

\subsubsection{Bereidheid om opleidingen en cursussen te volgen (in eigen tijd): verschillen tussen werknemers}

De werknemerssurvey bevat gedetailleerde informatie over werknemers en stelt ons instaat om te kijken in welke mate de relatie tussen leeftijd en de bereidheid om opleidingen en cursussen te volgen verschilt tussen typen werknemers. Specifiek hebben we gekeken naar de impact van 'structural career plateauing' (Lenz 2004) en de 'need for recovery'. Structural Career plateauing is een schaal die meet in welke mate werknemers ervaren dat zij geen progressie meer kunnen maken in hun organisatie en niet meer tot een hoger niveau kunnen uitgroeien. De need for recovery schaal komt uit de medische organisatiepsychologie (Mohren et al. 2010) en meet de herstelbehoefte. Deze drukt de moeilijkheid uit die werknemers subjectief ervaren in het herstel na een dag werk.

Van beide indicatoren kunnen we verwachten dat ze een belangrijke beperkende invloed hebben op de motivatie om te leren van oudere werknemers. De economische baten van opleidingen en cursussen zijn immers gering voor oudere werknemers die niet meer kunnen doorgroeien in hun huidige functie en tevens doorgaans weinig perspectief op de arbeidsmarkt hebben voor het vinden van een baan bij een nieuwe werkgever. Voor jongere werknemers, daarentegen, kan een hoge mate van career plateauing juist leiden tot een verhoogde trainingsmotivatie. Het is aannemelijk dat opleidingen en cursussen voor jongere werknemers juist wel hun baankansen verhoogd (Fouarge en Montizaan 2018). Wat betreft de need for recovery weten we dat de duur van herstelbehoefte toeneemt met leeftijd. De mogelijkheid bestaat derhalve dat het leeftijdseffect op de ingezette vrije uren hierdoor kan worden verklaard.

Figuren 4.4-4.6 laten marginale effecten zien van regressies waarin we ons basismodel hebben geïnteracteerd met de career plateauing en de need for recovery schalen. Uit Figuur 4.4 blijkt inderdaad dat oudere werknemers die nog progressie kunnen maken in hun organisatie en tot een hoger niveau kunnen uitgroeien meer gemotiveerd zijn om te blijven investeren in opleidingen en cursussen dan degenen die deze mogelijkheden niet meer hebben. Het demotiverend effect van career plateauing is het sterkst voor de jongeren en de ouderen, terwijl de verschillen voor 45- en 55-jarigen niet significant zijn.

Figuur 4.5 laat verder zien dat career plateauing een iets ander effect heeft op de bereidheid om opleidingen en cursussen te volgen in de eigen tijd. Werknemers die nog progressie kunnen maken zijn altijd meer bereid om een cursus te volgen in de 
eigen tijd. Maar 45- en 55-jarigen worden significant meer door een gebrek aan career plateauing positief beïnvloed dan jongeren of 65 -plussers.

FIGUUR 4.5 Career plateauing en bereidheid om opleidingen en cursussen te volgen

Predictive Margins with 95\% Cls
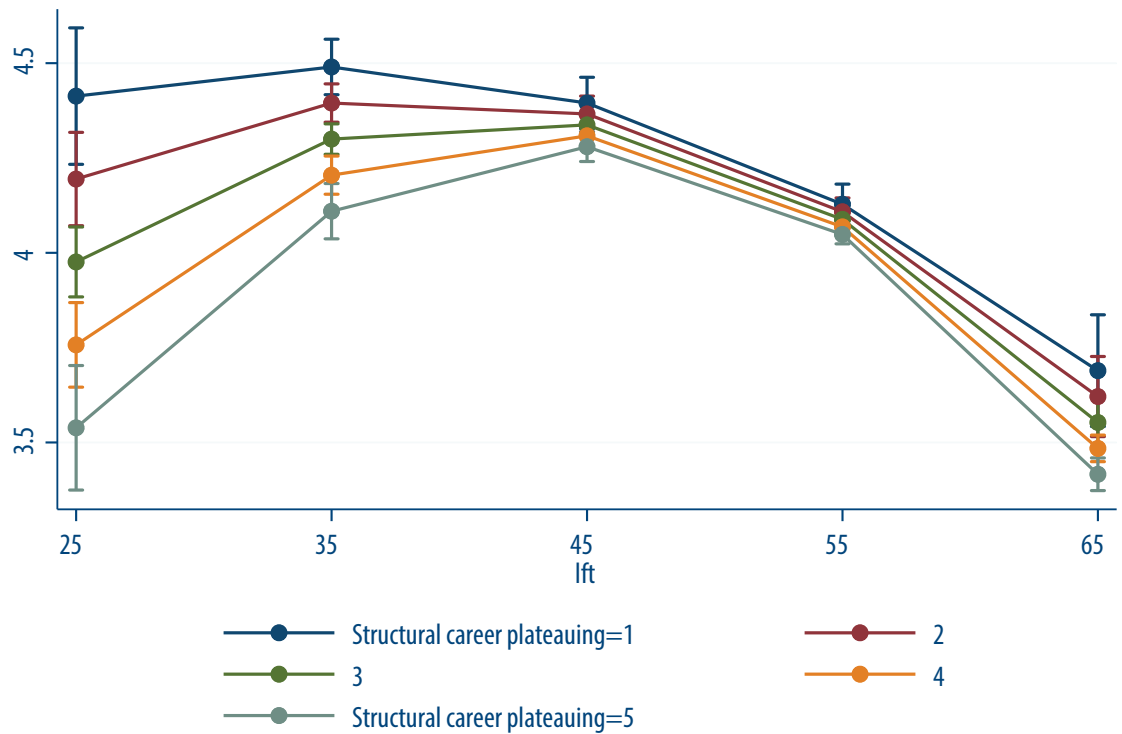
FIGUUR 4.6 Career plateauing en bereidheid om opleidingen en cursussen te volgen in eigen tijd Predictive Margins with $95 \%$ Cls

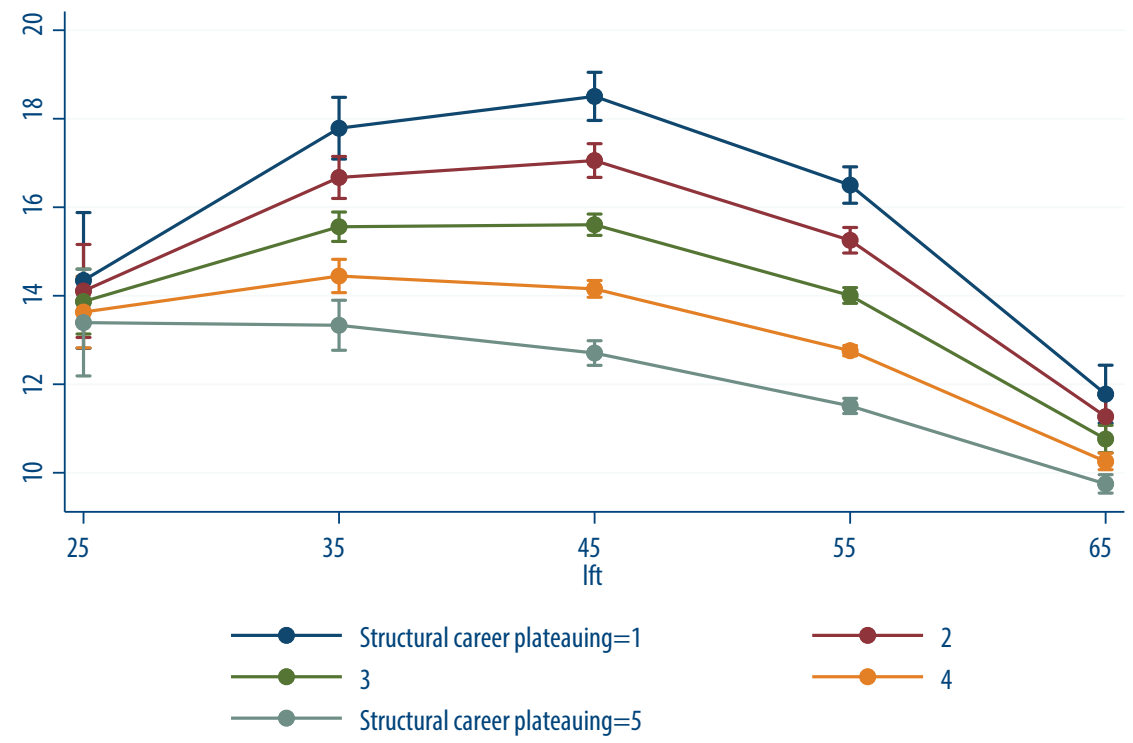

FIGUUR 4.7 Herstelbehoefte en bereidheid om opleidingen en cursussen te volgen in eigen tijd Predictive Margins with 95\% Cls

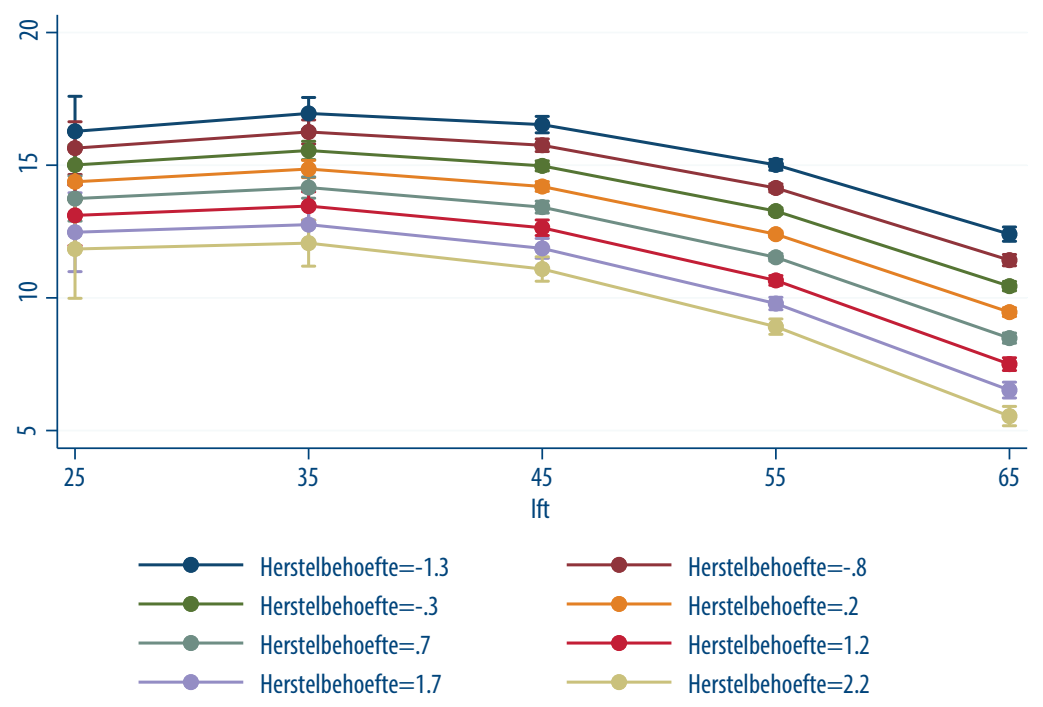


Maar ook de herstelbehoefte is een belangrijke determinant die beleidsmakers in ogenschouw moeten nemen. Uit Figuur 4.6 kunnen we opmaken dat de herstelbehoefte sterk gecorreleerd is aan het aantal vrije uren dat werknemers willen inzetten om een cursus te volgen. Des te lager de herstelbehoefte, des groter het aantal ingezette uren. Bovendien blijkt uit de figuur dat het negatieve effect van leeftijd op de ingezette vrije uren vooral sterk is voor werknemers met een grote herstelbehoefte. De hellingshoek verloopt significant steiler voor werknemers met een grote herstelbehoefte.

Figuren 4.7 en 4.8 laten vervolgens dat een hogere pensioenleeftijd gecorreleerd is met een hogere bereidheid om vrije tijd op te geven voor het volgen van een opleiding of cursus. Gemiddeld genomen willen werknemers die denken door te werken tot hun 7oste wel 6 uur meer vrije tijd opofferen. In zoverre is het aannemelijk dat de hogere pensioenleeftijd een belangrijke indicator is voor de werkmotivatie van werknemers. Echter, ook investeringsmotieven kunnen hier een rol spelen. Als werknemers langer denken door te werken kunnen zij immers langer profiteren van hun trainingsinvesteringen.

Uit de Figuren 4.7 en 4.8 blijkt verder dat pensioenverwachtingen een belangrijke interacterende rol spelen bij de bereidheid om vrije tijd op te offeren voor het volgen van opleidingen en cursussen. Terwijl werknemers die langer denken door te werken reeds zeer gemotiveerd zijn, zien we dat werknemers die eerder met pensioen denken te gaan meer gevoelig zijn voor het trainingsbudget en de mate waarin de opleiding of cursus bruikbaar is in hun privéleven. Dit duidt erop dat ook bij werknemers die eerder met pensioen denken te gaan mogelijk alsnog een investeringsmotief kan meespelen bij hun bereidheid om vrije tijd op te offeren voor het volgen van opleidingen en cursussen. ${ }^{1}$

1 Interessant in deze context is dat er ook een statistisch significante negatieve relatie is tussen career plateauing en de pensioenleeftijd. 
FIGUUR 4.8 Pensioenverwachting, trainingsbudget en bereidheid om opleidingen en cursussen te volgen in eigen tijd

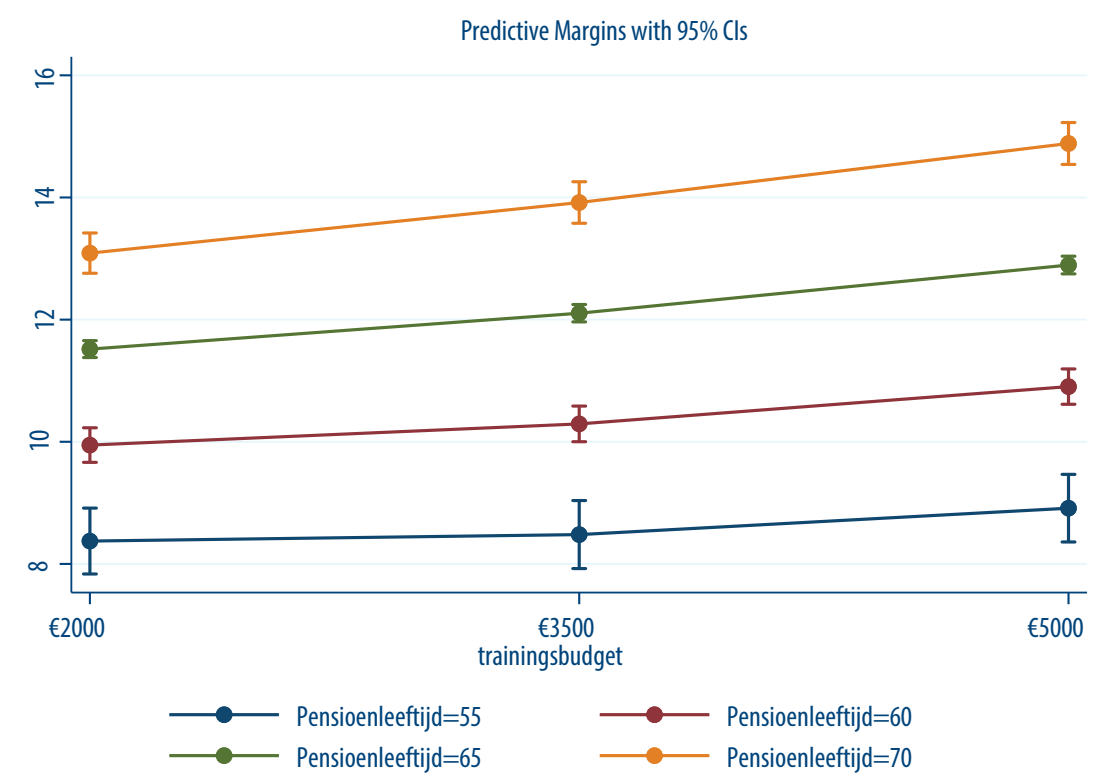


FIGUUR 4.9 Pensioenverwachting, bruikbaarheid privé en bereidheid om opleidingen en cursussen te volgen ion eigen tijd

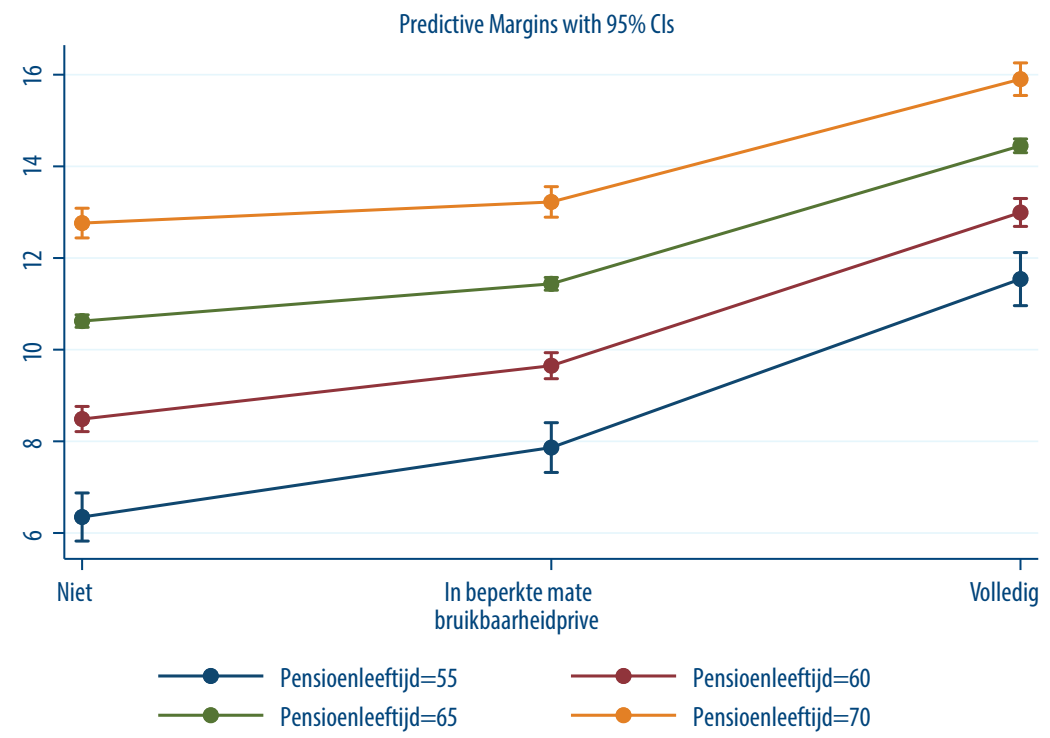





\section{CONCLUSIE}

Dit rapport geeft inzicht in welke mate oudere werknemers in Nederland bereid zijn te investeren in hun menselijk kapitaal alsmede in hoeverre werkgevers bereid zijn om te investeren. Op basis van de resultaten van twee stated preferences experimenten kunnen we vaststellen dat zowel werkgevers- als werknemersgedrag verantwoordelijk zijn voor de met leeftijd dalende participatie in opleidingen en cursussen. Desondanks zijn de resultaten voor werkgeversdiscriminatie iets sterker. De daling in werknemersmotivatie om een cursus te volgen verloopt vrij vlak.

Op basis van de resultaten kunnen we verder enkele concrete beleidsaanbevelingen doen. Allereerst is het opvallend dat de relatie tussen trainingskansen en leeftijd veel vlakker verloopt voor werkgevers die relatief veel vaste contracten aanbieden en tevens veel ontwikkelgesprekken voeren met hun werknemers. Hoewel mogelijk ook andere organisatiekenmerken hier een rol kunnen spelen, duidt dit resultaat er wel op dat stabiele werksituaties, waarin wordt ingezet op een langere arbeidsrelatie en duurzame ontwikkeling, een positieve uitwerking hebben op een leven lang leren. Zowel werkgevers als werknemers worden dan gestimuleerd om na te denken over welke investeringen nodig zijn om de bestaande arbeidsrelatie op de lange termijn te laten slagen en beide partijen hebben incentives om te blijven investeren. Dit betekent dan ook dat meer flexibiliteit op de arbeidsmarkt en het afbreken van de bescherming van de arbeidspositie van oudere werknemers weleens averechts kunnen werken voor een leven lang leren. Werkgevers hebben zo immers minder incentives om te blijven investeren in het menselijk kapitaal van hun oudere werknemers. Belangrijk is daarnaast dat werkgevers meer moeten gaan differentiëren in hun trainingsbeleid tussen oudere en jongere werknemers. In onze vignettenexperiment vinden wij dat werkgevers, zoals ook in eerder onderzoek is gebleken, geen onderscheid maken in de allocatie van typen training tussen werknemers met verschillende leeftijden, ondanks het feit dat werknemers uit verschillende leeftijdsgroepen verschillende comparatieve voordelen hebben.

Een andere optie is dat werkgevers meer buitenspel worden gezet bij de individuele menselijke kapitaal ontwikkeling van werknemers. Het Nederlandse kabinet zet zich in voor een doorbraak op het gebied van een leven lang leren en een sterke en positieve leercultuur. In het regeerakkoord is derhalve afgesproken dat het kabinet in dit kader wil bevorderen dat iedereen een individueel budget voor algemene scholing en ontwikke- 
ling (leerrekening) tot zijn of haar beschikking krijgt. Het idee achter individuele leerrekeningen is dat iedereen zo meer regie krijgt over zijn of haar loopbaan en zich beter kan aanpassen aan veranderingen op de arbeidsmarkt. Werknemers krijgen daarmee meer eigen verantwoordelijkheid voor de ontwikkeling van hun competentieprofiel en duurzame inzetbaarheid op de arbeidsmarkt. Er zijn twee manieren waarop het kabinet dit wil gaan stimuleren:

1. via een fiscale regeling (verbeterde fiscale facilitering?) voor private individuele leerrekeningen

2. via een uitgavenregeling voor publieke individuele leer-en ontwikkelbudgetten, die naar verwachting in 2020 kan worden ingevoerd.

Een belangrijke kanttekening daarbij is echter wel, zoals reeds gezegd, dat voortdurende bijscholing doorgaans wel effectiever zal zijn dan omscholing en dat werknemers voldoende begeleiding krijgen om te komen tot een zo optimaal mogelijke investeringsstrategie.

Maar ook de werknemersmotivatie kan verder worden gestimuleerd. Allereerst is van belang om te beseffen dat werknemers meer gemotiveerd worden als zij de vaardigheden die zij trainen ook kunnen gebruiken in hun privéleven. Ten tweede is autonomie in de onderwerpkeuze voor de opleiding of cursus van cruciaal belang voor de motivatie. Werknemers zijn veel meer gemotiveerd om te blijven investeren als zij medezeggenschap krijgen in de aard en wij waarop geïnvesteerd gaat worden. Ten derde, career plateauing is een cruciale factor die oudere werknemers demotiveren om te blijven investeren. Wil men een leven lang leren stimuleren over een langere levensduur, dan zal men ook loopbaanprofielen moeten aanpassen zodat werknemers nog steeds het gevoel hebben dat investeren in hun menselijk kapitaal beloond wordt. De stijging van met ervaring oplopende loonprofielen zou meer moeten worden uitgespreid over de steeds langere wordende loopbanen van werknemers. De voortdurende uitstel van pensionering zorgt ervoor dat werknemers steeds vaker voor een langere periode een plateau ervaren als loonprofielen hier niet op aangepast worden. Hierdoor kunnen werknemers ook minder gestimuleerd worden om langer door te werken. Het is daarbij ook van belang dat career plateauing hand in hand gaat met een verwachte lagere pensioenleeftijd. Career plateauing kan dus ook een belangrijke barrière vormen voor de arbeidsparticipatie van ouderen.

Ten slotte laten onze resultaten zien dat oudere werknemers minder bereid zijn om hun vrije tijd op te offeren voor het volgen van opleidingen en cursussen. Hier speelt onder andere de grotere herstelbehoefte mee onder ouderen. Een leven lang leren kan dus verder gestimuleerd worden door werknemers de mogelijkheid te geven om te investeren in opleidingen en cursussen gedurende werktijd. 


\section{LITERATUUR}

Altonji, J. G., \& Pierret, C. R. (2001). Employer learning and statistical discrimination. The Quarterly Journal of Economics, 116(1), 313-350.

Aguinis, H., \& Kraiger, K. (2009). Benefits of training and development for individuals and teams, organizations, and society. Annual review of psychology, 60, 451-474.

Argote, L., \& Ingram, P. (2000). Knowledge transfer: A basis for competitive advantage in firms. Organizational behavior and human decision processes, 82(1), 150-169.

Becker, G. S. (1962). Investment in human capital: A theoretical analysis. Journal of political economy, 70(5, Part 2), 9-49.

Arulampalam, W., Booth, A. L., \& Bryan, M. L. (2004). Training in europe. Journal of the European Economic Association, 2(2区3), 346-360.

Becker, G. S. (1975). Front matter, human capital: a theoretical and empirical analysis, with special reference to education. In Human Capital: A Theoretical and Empirical Analysis, with Special Reference to Education, Second Edition (pp. 22-0). NBER

Bertrand, M., Chugh, D., \& Mullainathan, S. (2005). Implicit discrimination. American Economic Review, 95(2), 94-98.

CK Chiu, W., Chan, A. W., Snape, E., \& Redman, T. (2001). Age stereotypes and discriminatory attitudes towards older workers: An East-West comparison. Human relations, 54(5), 629-661.

Cromwell, S. E., \& Kolb, J. A. (2004). An examination of work冈environment support factors affecting transfer of supervisory skills training to the workplace. Human resource development quarterly, 15(4), 449-471.

Eichar, D. M., Norland, S., Michael Brady, E., \& Fortinsky, R. H. (1991). The job satisfaction of older workers. Journal of Organizational Behavior, 12(7), 609-620.

Finkelstein, L. M., \& Burke, M. J. (1998). Age stereotyping at work: The role of rater and contextual factors on evaluations of job applicants. The Journal of general psychology, 125(4), 317-345.

Fouarge, D., van Eldert, P., de Grip, A., Künn, A., \& Poulissen, D. (2018). Nederland in leerstand. ROA-R$2018 / 4$

Gist, M., Rosen, B., \& Schwoerer, C. (1988). The influence of training method and trainee age on the acquisition of computer skills. Personnel Psychology, 41(2), 255-265.

Grip, A. de., \& Van Loo, J. (2002). The economics of skills obsolescence: a review. In The Economics of Skills Obsolescence (pp. 1-26). Emerald Group Publishing Limited.

Hainmueller, J., Hangartner, D., \& Yamamoto, T. (2015). Validating vignette and conjoint survey experiments against real-world behavior. Proceedings of the National Academy of Sciences, 112(8), 2395-2400. 
Hansson, B. (2008). Job-Related Training and Benefits for Individuals: A Review of Evidence and Explanations. OECD Education Working Papers, No. 19. OECD Publishing (NJ1).

Henkens, K., Van Solinge, H., \& Cozijnsen, R. (2009). Let go or retain? A comparative study of the attitudes of business students and managers about the retirement of older workers. Journal of Applied Social Psychology, 39(7), 1562-1588.

Hirsch, B. T., Macpherson, D. A., \& Hardy, M. A. (2000). Occupational age structure and access for older workers. ILR Review, 53(3), 401-418

Hutchens, R. M. (1988). Do job opportunities decline with age?. ILR Review, 42(1), 89-99.

Karpinska, K., Henkens, K., \& Schippers, J. (2011). The recruitment of early retirees: a vignette study of the factors that affect managers' decisions. Ageing \& Society, 31(4), 570-589.

Karpinska, K., Henkens, K., \& Schippers, J. (2013). Retention of older workers: Impact of managers' age norms and stereotypes. European Sociological Review, 29(6), 1323-1335.

Karpinska, K., Henkens, K., Schippers, J., \& Wang, M. (2015). Training opportunities for older workers in the Netherlands: A Vignette Study. Research in Social Stratification and Mobility, 41, 105-114

Künn-Nelen, A., Poulissen, D., Van Eldert, P., Fouarge, D., \& Grip, A. de. (2018). Leren onder werkenden met een kwetsbare positie op de arbeidsmarkt. ROA-R-2018/5.

Lahey, J. N. (2008). Age, women, and hiring an experimental study. Journal of Human resources, 43(1), 30-56.

Lawrence H. Ganong and Marilyn Coleman Source: Journal of Marriage and Family, Vol. 68, No. 2 (May, 2006), pp. 455-468

Lazazzara, A., Karpinska, K., \& Henkens, K. (2013). What factors influence training opportunities for older workers? Three factorial surveys exploring the attitudes of HR professionals. The International Journal of Human Resource Management, 24(11), 2154-2172.

Lentz, E. (2004). The link between the career plateau and mentoring: Addressing the empirical gap. The Catholic University of America.

Louviere, J. J., Hensher, D. A., \& Swait, J. D. (2000). Stated choice methods: analysis and applications. Cambridge university press.

Maurer, T. J. (2001). Career-relevant learning and development, worker age, and beliefs about selfefficacy for development. Journal of Management, 27, 123-140.

Maurer, T. J., Barbeite, F. G., Weiss, E. M., \& Lippstreu, M. (2008). New measures of stereotypical beliefs about older workers' ability and desire for development: Exploration among employees age 40 and over. Journal of Managerial Psychology, 23, 395-418.

Maximiano, S. (2011). Two to tango: the determinants of workers' and firms' willingness to participate in job-related training. West Lafayette, IN: Purdue University.

Mohren, D. C. L., Jansen, N. W. H., \& Kant, I. J. (2010). Need for recovery from work in relation to age: a prospective cohort study. International archives of occupational and environmental health, 83(5), 553-561.

Montizaan, R., \& Fouarge (2016), D. The impact of employer's characteristics and beliefs on propensity to hire older job applicants. Netspar Discussion paper DP 01/2016-054

$\mathrm{Ng}, \mathrm{T}$. and Feldman, D. (2008), "The relationship of age to ten dimensions of job performance", Journal of Applied Psychology, Vol. 93 No. 2, pp. 392-423

$\mathrm{Ng}, \mathrm{T}$. and Feldman, D. (2012), "Evaluating six common stereotypes about older workers with metaanalytical data", Personnel Psychology, Vol. 65 No. 4, pp. 821-858. 
Organisation for Economic Co-operation and Development (OECD) (2000); Literacy in the Information Age: Final Report of the International Adult Literacy Survey, OECD and Statistics of Canada, Paris Phelps, E. S. (1972). The statistical theory of racism and sexism. The american economic review, 62(4), 659-661.

Schwab, S. (1986). Is statistical discrimination efficient?. The American Economic Review, 76(1), 228-234.

Taylor, B. J. (2005). Factorial surveys: Using vignettes to study professional judgement. British Journal of Social Work, 36(7), 1187-1207.

Telser, H., \& Zweifel, P. (2007). Validity of discrete-choice experiments evidence for health risk reduction. Applied Economics, 39(1), 69-78.

Van Vianen, A. E., Dalhoeven, B. A., \& De Pater, I. E. (2011). Aging and training and development willingness: Employee and supervisor mindsets. Journal of Organizational Behavior, 32(2), 226-247.

Warr, P. and Fay, D. (2001), "Short report: age and personal initiative at work", European Journal of Work and Organizational Psychology, Vol. 10 No. 3, pp. 343-353.

Zwick, T. (2015). Training older employees: what is effective?.International Journal of Manpower, 36(2), 136-150. 



\section{APPENDIX A: VOORBEELD}

\section{Voorbeeld Werkgeversexperiment}

Er volgen nu een aantal vragen waarin wij u vragen zich voor te stellen dat binnen uw organisatie budget is vrijgemaakt voor het volgen van trainingen en cursussen op HBOniveau. Wij vragen $u$ een telkens een keuze te maken tussen 2 werknemers die binnen uw organisatie beschikbaar zijn om een training te volgen. De werknemers verschillen uitsluitend met betrekking tot hun geslacht, leeftijd, opleidingsniveau, relevante ervaringsjaren en de match tussen vakopleiding en functie. Voor de rest zijn zij volledig identiek.

Stel dat uw organisatie een training of cursus aanbiedt op HBO-niveau dat ingaat op de volgende onderwerpen?

\section{Onderwerp: Informatie zoeken en verwerking}

Hieronder vindt $u$ de beschrijving van twee werknemers die beschikbaar zijn voor deze cursus. Stel u moet één van deze werknemers deze cursus aanbieden, aan welke persoon geeft u dan de voorkeur?

Werknemer A

Leeftijd: 35 jaar

Geslacht: Vrouw

Werkervaring: 5 jaar

Werkuren per week: 40 uur

Opleidingsniveau: MBO
Werknemer B

Leeftijd: 55 jaar

Geslacht: Man

Werkervaring: 15 jaar

Werkuren per week: 32 uur

Opleidingsniveau: W0 


\section{Voorbeeld Werkgeversexperiment}

Stel uw werkgever stelt aan u een trainingsbudget beschikbaar voor een training. De training zal 5 volledige werkdagen duren van 8 uur. In totaal duurt de cursus dus 40 uur. De cursusdagen worden verspreid over twee maanden. Uw werkgever vraagt daarbij of u bereid bent om een gedeelte van de training te volgen in uw eigen tijd.

U krijgt hieronder zes keer een omschrijving van de training waarbij zij op een viertal kenmerken verschillen. De vier kenmerken zijn:

1. Het trainingsbudget dat door uw werkgever beschikbaar is gesteld

2. De mate waarin de vaardigheden die worden aangeleerd tijdens de training bruikbaar zijn in uw werk

3. De mate waarin de vaardigheden die worden aangeleerd tijdens de training bruikbaar zijn in uw privéleven

(denk bijvoorbeeld aan communicatie, planningsvaardigheden, computervaardigheden etc.)

4. Persoon die het onderwerp van de training kiest

$\mathrm{U}$ wordt vervolgens vijf keer gevraagd hoeveel uren van uw eigen tijd u bereid bent te besteden aan de training.

De training zal 5 volledige werkdagen duren van 8 uur. In totaal duurt de cursus dus $\mathbf{4 0}$ uur. De cursusdagen worden verspreid over twee maanden. De training bevat de volgende kenmerken:

\begin{tabular}{|l|l|}
\hline Trainingsbudget: & 2000 \\
\hline Bruikbaarheid in uw werk: & In uw organisatie en organisaties binnen en buiten uw bedrijfstak \\
\hline Bruikbaarheid in uw privéleven: & In beperkte mate \\
\hline Persoon die training kiest: & Uzelf \\
\hline
\end{tabular}

Hoeveel uur van uw eigen tijd bent u bereid om vrij te maken voor de training in deze twee maanden? 


\section{APPENDIX B: SECTORUITKOMSTEN}

FIGUUR B1 Structural career plateauing per sector

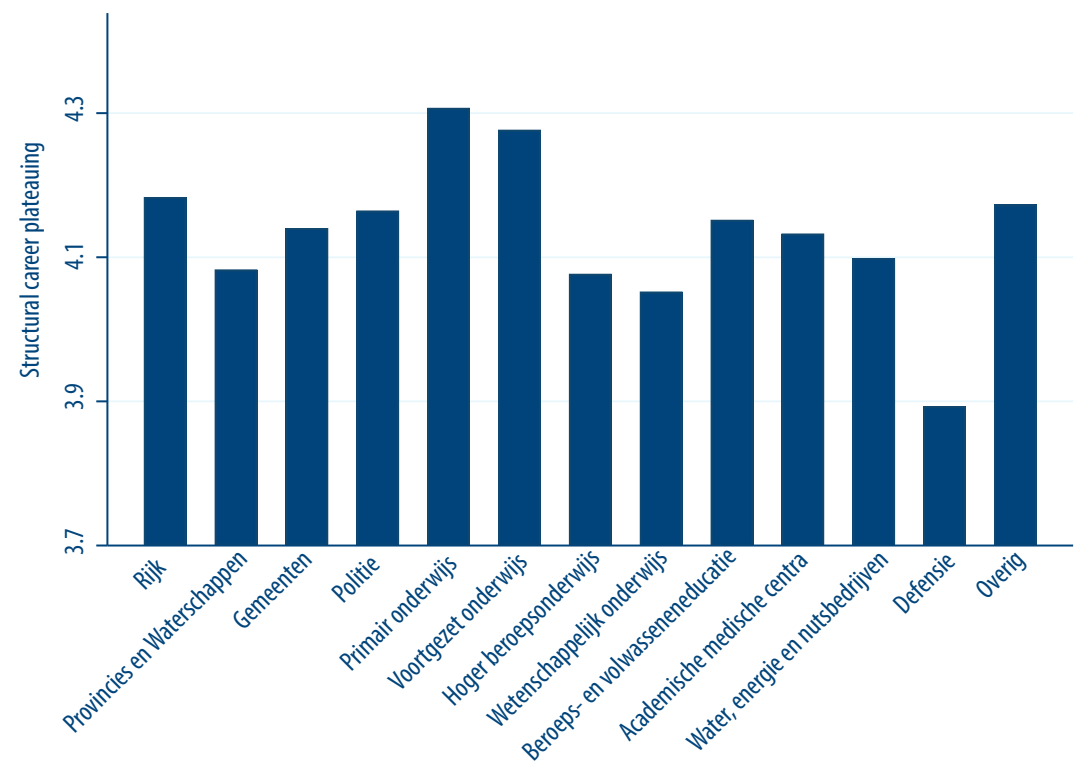

Career plateauing is een schaal die meet in welke mate werknemers ervaren dat zij geen progressie meer kunnen maken in hun organisatie en niet meer tot een hoger niveau kunnen uitgroeien (structural plateauing), en in welke mate zij nog voldoende inhoudelijke uitdaging vinden in hun werk (content plateauing).

Uit figuur B1 blijkt dat vooral in het primair onderwijs en het voortgezet onderwijs en het rijk werknemers ervaren dat zij geen progressie meer kunnen maken. Bij defensie, het wetenschappelijk onderwijs en het hoger beroepsonderwijs geven werknemers het minst vaak aan dat zij een plateau ervaren. 


\section{FIGUUR B2 Content career plateauing per sector}

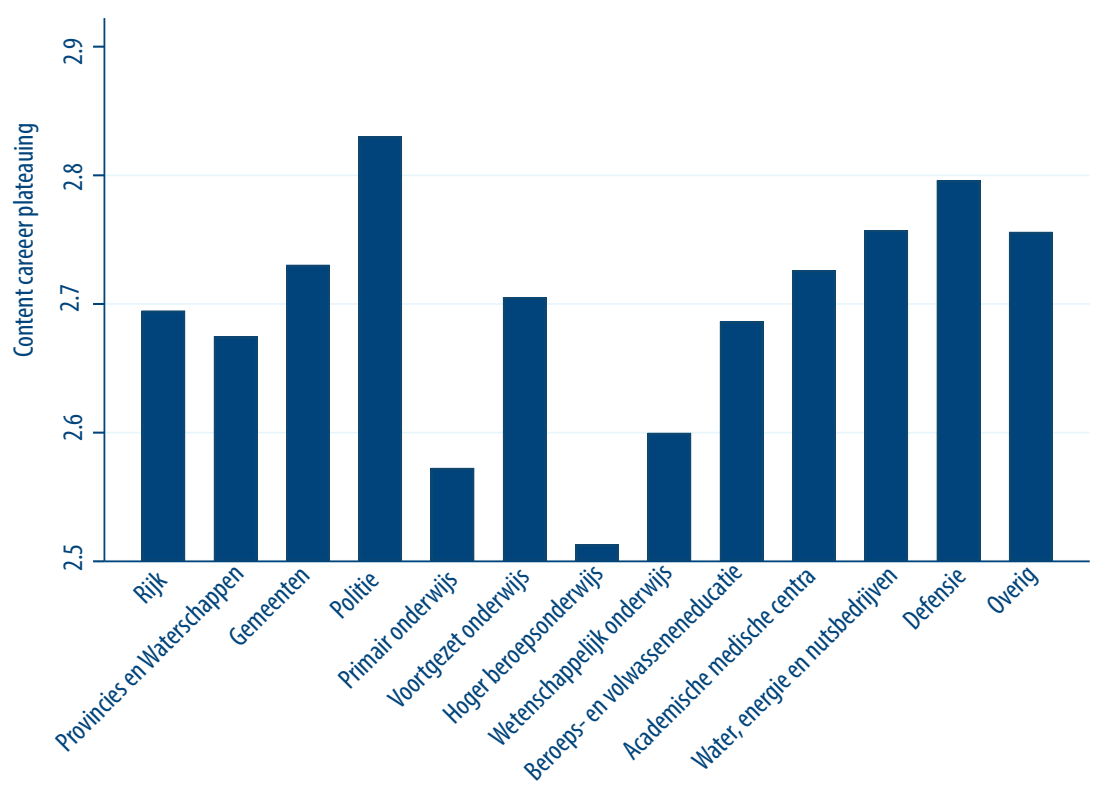

Bij de politie, defensie, water energie en nutsbedrijven geven werknemers vaker aan dat zij geen inhoudelijke uitdaging ervaren. Bij hoger beroepsonderwijs, wetenschappelijk onderwijs en het primair onderwijs hebben werknemers de meeste inhoudelijke uitdaging. 
FIGUUR B3 Overuren in afgelopen maand

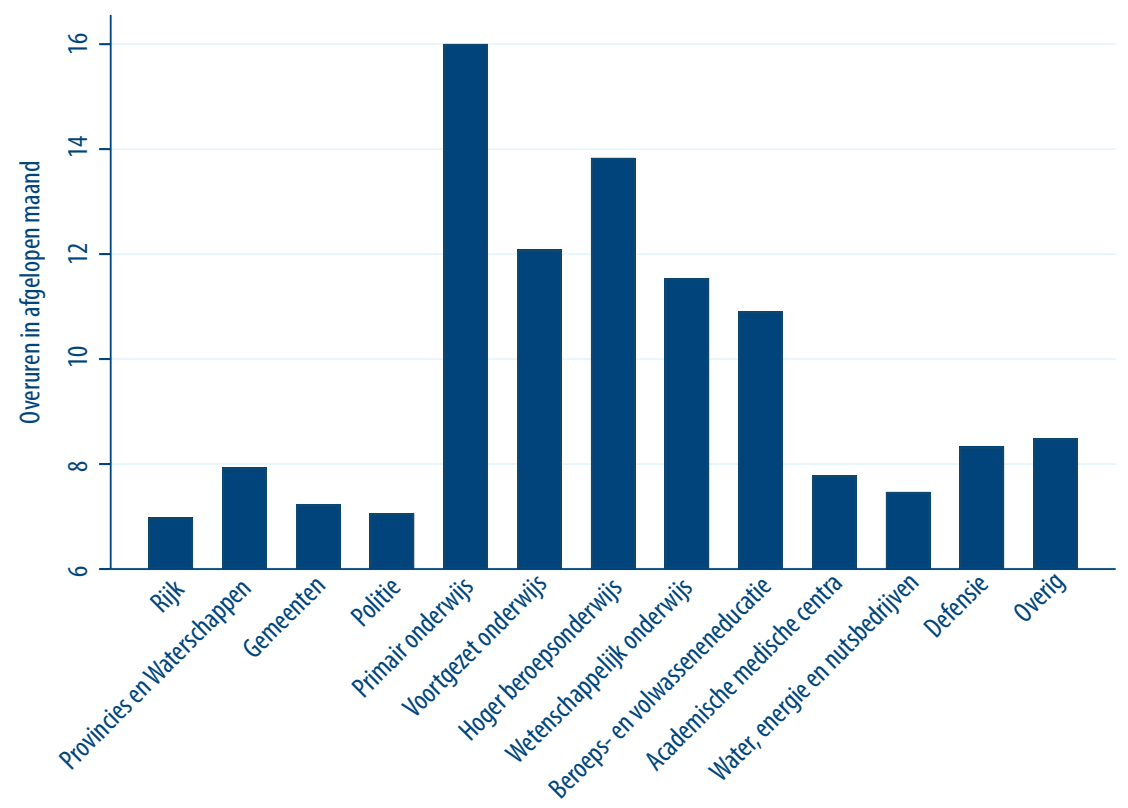

Figuur B3 geeft weer hoeveel overuren werknemers hebben gemaakt in de afgelopen maand. Deze overuren geven een goede indictie van de werkdruk per sector. Het blijkt dat het aantal overuren aanzienlijk hoger is in de onderwijssectoren. Terwijl bij primair onderwijs ruim 16 overuren worden gedraaid, is dit bij de politie maar 7 uur. Hierbij dient te worden gezegd dat bij het primair onderwijs ook relatief veel mensen in deeltijd werken. Bij de andere onderwijssectoren is dit minder. 
FIGUUR B4 Van plan om de komende twee maanden een opleiding te volgen

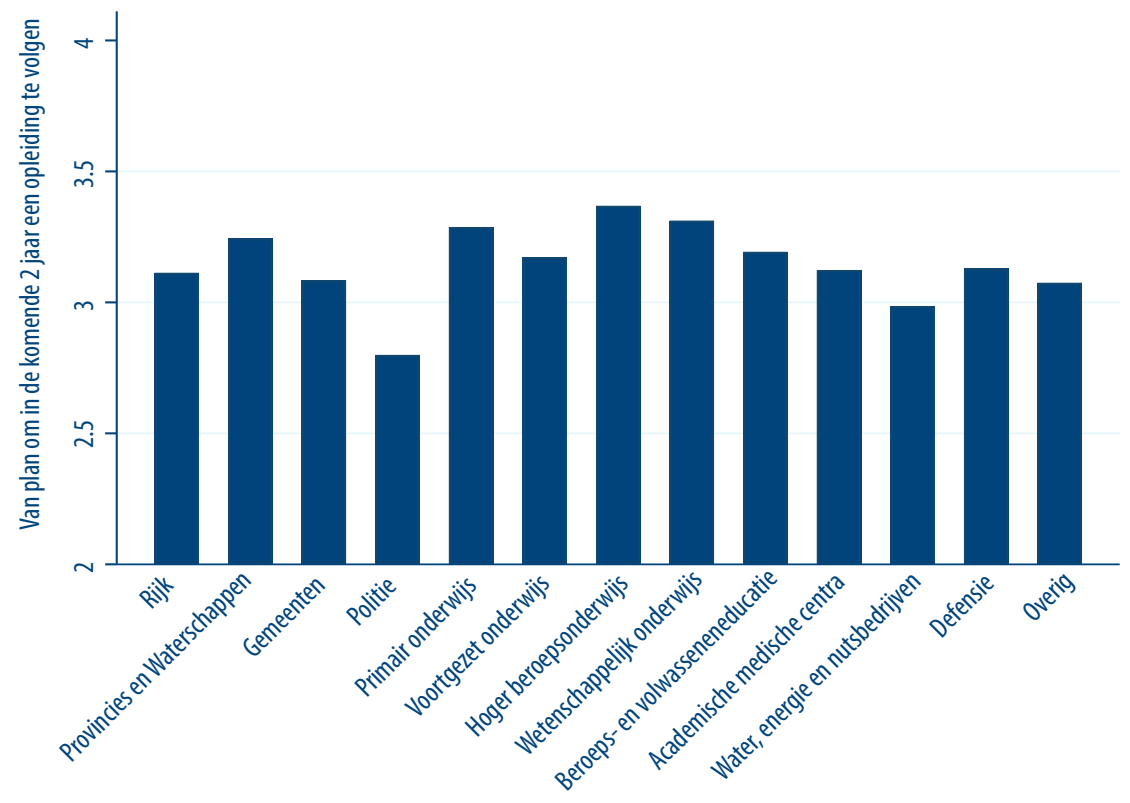

Figuur B4 laat zien op een schaal van 1 tot 5 in welke mate mensen van plan zijn een opleiding te volgen in de komende twee jaar. De variatie tussen sectoren is niet heel erg groot. Wel valt op dat er iets meer gepland wordt om te trainen in de onderwijssectoren. Bij de politie, water, energie en nutsbedrijven en gemeenten ligt deze score wat lager. 
FIGUUR B5 Bereidheid om een cursus te volgen voor de huidige functie

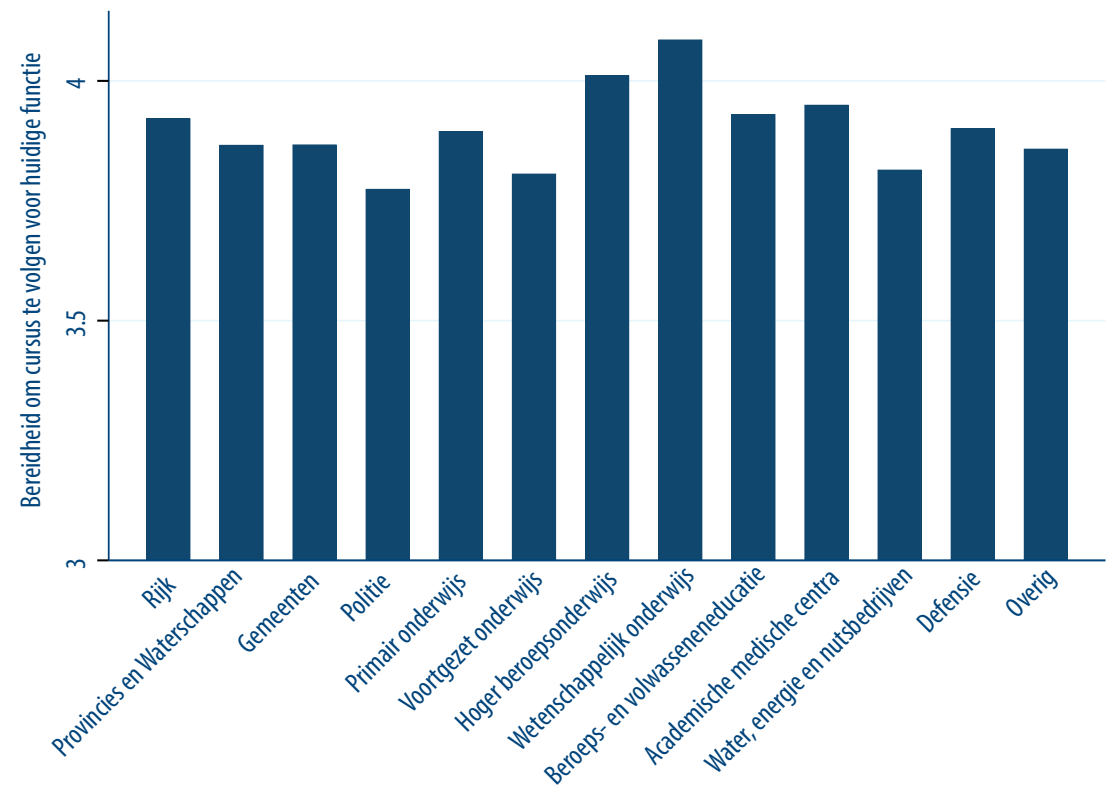

Figuur B5 laat zien op een schaal van 1 tot 5 in welke mate mensen bereid zijn om een cursus te volgen voor hun huidige functie. De bereidheid is het grootst in het wetenschappelijk en hoger beroepsonderwijs. De politie, het voortgezet onderwijs en de water, energie en nutsbedrijven blijven daarentegen achter 
FIGUUR B6 Weinig profijt van het volgen van een cursus

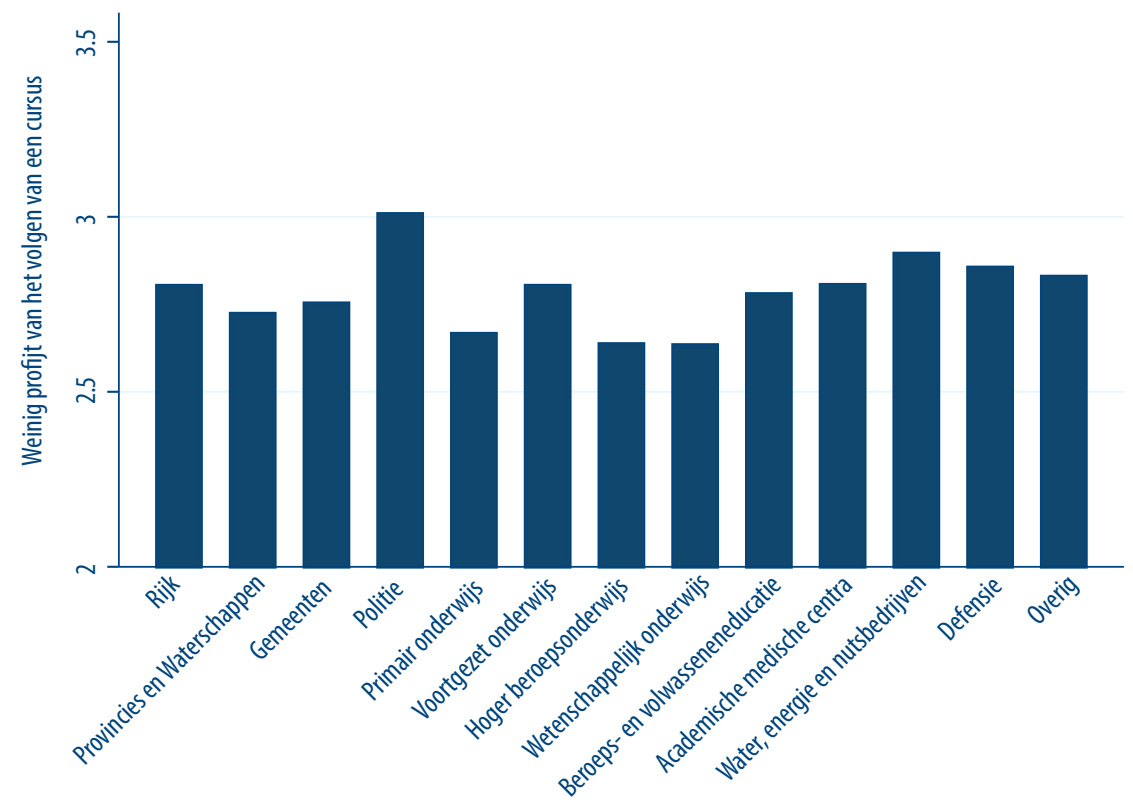

Figuur B6 laat zien op een schaal van 1 tot 5 in welke mate mensen weinig profijt ervaren van het volgen van een opleiding. Vooral bij de politie, water, energie en nutsbedrijven ervaren werknemers maar weinig profijt van het volgen van een opleiding. Bij het wetenschappelijk en hoger beroepsonderwijs is deze score het laagst, gevolgd door de provincies en waterschappen. 
FIGUUR B7 Verwachte pensioenleeftijd

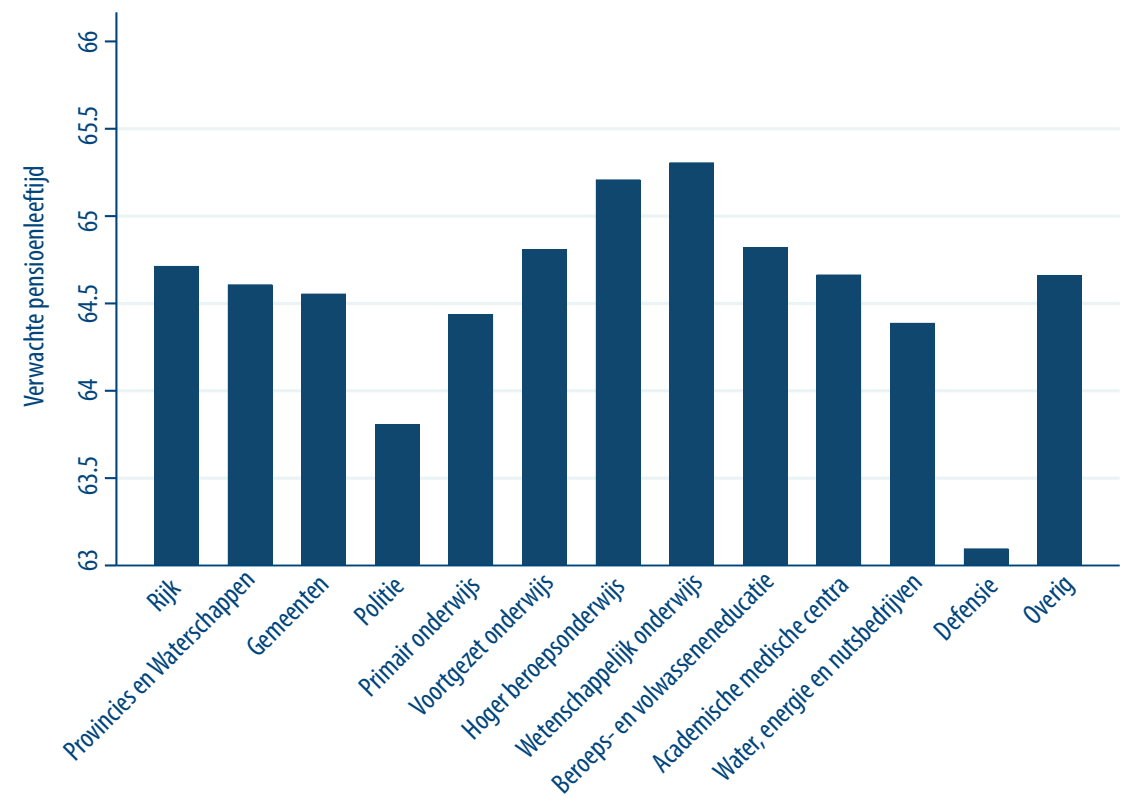

De verwachte pensioenleeftijd is de afgelopen jaren fors gestegen. Opvallend is echter dat er forse verschillen zichtbaar blijven tussen de verschillende sectoren. Bij het wetenschappelijk en hogerberoepsonderwijs en denken uit te treden ruim boven de 65 jaar. Bij de defensie en politie denken werknemers op hun 63ste uit te treden. Bij het primair onderwijs denken werknemers ongeveer 5 maanden tot bijna één jaar eerder uit te treden dan bij andere onderwijssectoren. 
FIGUUR B8 Need for recovery

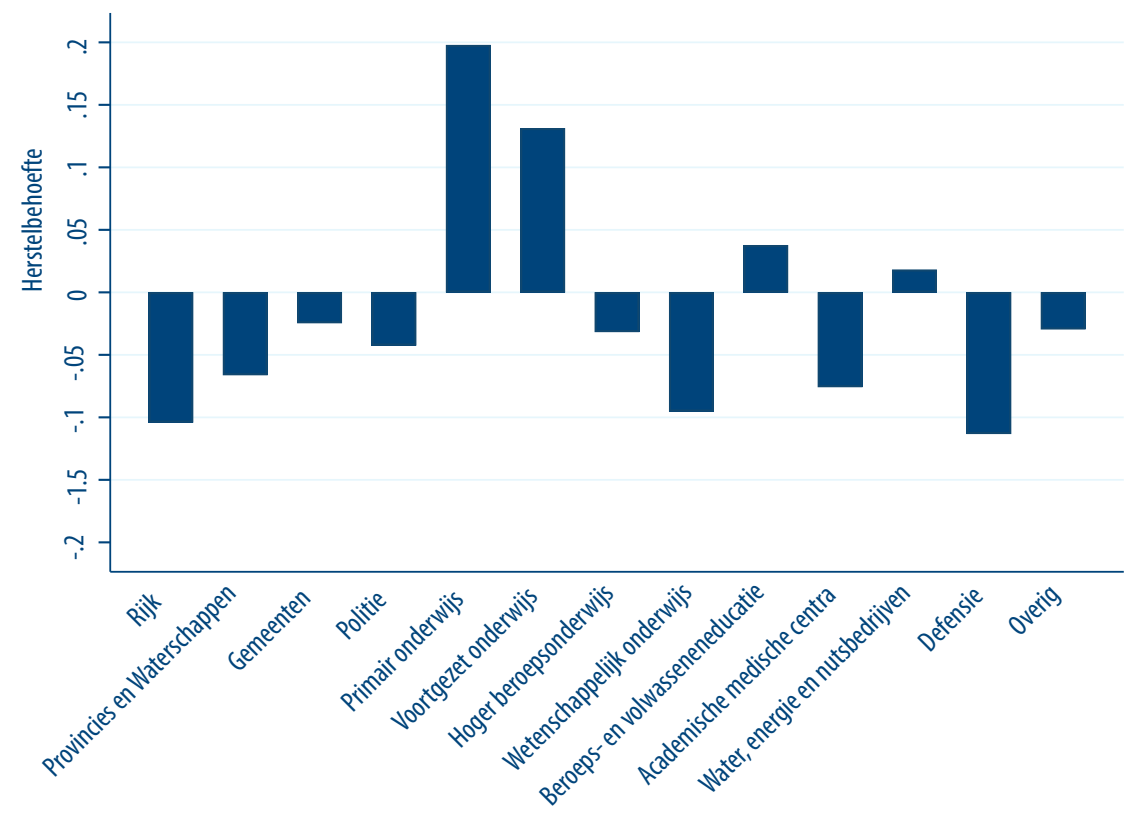

De need for recovery schaal komt uit de medische organisatiepsychologie (Mohren et al. 2010) en meet de herstelbehoefte. Deze drukt de moeilijkheid uit die werknemers subjectief ervaren in het herstel na een dag werk. De need for reovery schaal die in Figuur B8 wordt getoond is gestandaardiseerd op o. In de figuur blijkt dat de herstelbehoefte relatief hoog is in het primair onderwijs en het voortgezet onderwijs, de beroeps en volwasseneneducatie en de water, energie en nutsbedrijven. Dit kan komen door de aard van het werk, maar ook door selectie van specifieke typen werknemers in bepaalde sectoren. Meer onderzoek is nodig om te achterhalen wat hier nu de specifieke oorzaakis. Opvallend is wel dat het aantal overuren in het primair onderwijs ook relatief hoog is, en dat er een relatief hoge mate van structural plateauing wordt ervaren binnen deze sector. De herstelbehoefte is het laagst bij defensie (mede veroorzaakt door de lagere gemiddelde leeftijd van de werknemers in deze sector), het wetenschappelijk onderwijs, en het rijk. 
